\title{
Hint üslubunda yabancılaştırma
}

\section{Emrullah YAKUT ${ }^{1}$}

\begin{abstract}
APA: Yakut, E. (2019). Hint üslubunda yabancılaştırma. RumeliDE Dil ve Edebiyat Araştırmaları
\end{abstract} Dergisi, (16), 380-408. DOI: 10.29000/rumelide.618970

\section{$\ddot{O} \mathbf{z}$}

Hint üslubunun birçok özelliğini saymak mümkündür. Ancak bu üslubun en önemli ayırt edici özelliklerinden biri ma'nâ-yı bîgâne'dir. Hint üslubu şairlerince farklı bağlamlarda kullanılabilen ma'nâ-yı bîgâne tabirinin bir anlamı da garip, zor, karmaşı ve alışılmadık anlamlardır. 1917'de Rus edebiyat kuramcısı Shklovsky'nin ortaya attığı yabancılaştırma kuramı ise metnin algılanışının yavaşlatılması gerektiğini savunur ve bunu temin etmek için de tanıdık şeylerin bilinmeyen ve tuhaf bir biçimde sunulmasını salık verir. Hint üslubunda yabancılaştırma yollarının tedkik edildiği bu çalışmada Türk ve Fars şiirinden örnekler ele alınmış, kimi beyitlerde aşırı hayale ve girift anlam münasebetlerine dayanan bazı noktalar tahlil edilerek bu şiirin anlam dünyasına nüfuz edilmeye çalışılmıştır.

Anahtar kelimeler: Sebk-i Hindî, yabancılaştırma, ma'nâ-yı bîgâne, bîgâne-sâzî, âşinâyî-zodâyî.

\section{Defamiliarization in Sabk-e Hindi poetry}

\begin{abstract}
There are several characteristics of Sabk-e Hindi (Indian style) poetry whereas the most distinctive feature of this style is "ma'nâ-yi bigane". Along with different contexts that Sabk-e Hindi poets apply the term, one particular meaning of "ma'na-yi bigane" is "strange, difficult, complicated, unusual and unfamiliar meaning". The concept of "defamiliarization" that Russian literary theorist Shlovsky brought up in 1917 asserts that perception of the literary text must be decelerated and suggests that familiar things need to be presented in unfamiliar and unusual ways to enable this. This work is examines the ways of defamiliarization in Indian style poetry, discussing examples from Turkish and Persian poetry and tries to explore the semantic world of the poetry by analyzing some points that depend on farfetched imagination and complicated meaning references.
\end{abstract}

Keywords: Indian style poetry, mana-yi bigane [strange meaning], bigane-sazi [making unfamiliar], ashinayi-zodayi [erasing the familiarity].

\section{Giriș}

\section{Ma'nâ-yı bîgâne}

Üslup bir yazar, şair, veya devri diğerlerinden ayıran kendine mahsus ifade biçimidir (Cuddon 2013: 688). Hint üslubuyla kudemanın şiiri arasındaki farklara baktığımızda ise bunların bazılarının keyfiyetten ziyade kemmiyetle alakalı hususlar olduğu görülür. Mesela mübâlağa, irsâl-i mesel, teşhîs ve îhâm gibi edebî sanatlar önceki devirlere nazaran daha çok kullanılmıştır. Fakat bunlar Hint üslubu

$1 \quad$ Dr. Öğr. Üyesi, Mardin Artuklu Üniversitesi, Edebiyat Fakültesi,Türk Dili ve Edebiyatı Bölümü (Mardin, Türkiye), emrullahyakut@gmail.com, ORCID ID: oooo-0002-1268-1806 [Makale kayıt tarihi: 26.06.2019-kabul tarihi:20.09.2019; DOI: 10.29000/rumelide.618970] 
şairlerine mahsus unsurlar değildir. Dolayısıyla bazı edebî sanatların çok kullanılması Hint üslubunun bir özelliği olsa da bu üslup şairlerini teşhis etmemizde bize yeterince yardımcı olmaz. Bu üslubun önemli bir ayırt edici vasfı ma’nâ-yı bîgâne diye adlandırılan alışılmamış anlamlardır.

Sebk-i Hindî şairlerinin mısralarında rastlanan "ma'nâ-yı bîgâne, hayâl-i garîb, mazmûn-ı dûr, mazmûn-ı pîçîde, ma’nâ-yı rengîn, ma’nâ-yı nâzik, hayâl-i nâzik, fikr-i bârîk” gibi tabirler bu üslup şairlerinin alışılmamış (bîgâne, garîb), uzak çağrışımlı (dûr), karmaşık (pîçîle) ve ince anlamlar (bârîk, nâzik) bulma konusunda şuurlu bir tercih içinde olduklarının göstergesidir.

Ma'nâ-yı bîgâne daha çok "yeni ve orijinal mazmunlar" anlamında kullanılmaktadır. Bu bağlamda şairler yeni çağrışım ağları ve mazmunlar yaratmaya ve yeni anlam ilişkileri keşfetmeye çalışmıştır. Bununla birlikte Hint üslubu şairlerinin bu tabiri yabancllaştırma kavramıla benzer bir yönde de kullandıkları söylenebilir (Âlâştî 74: 1384):

$$
\text { تلخ كردى زندگى بر آثنايان سخن / اين قدر صائب تلاش معنى بيحانه جِيس (Sâib G.1243/6) }
$$

(Şiirden anlayanlara hayatı zehir ettin. Ey Sâib, bu kadar "yabancı mana” nedir?)

Görüldüğü gibi şairin burada kastettiği yeni mazmun değil, anlaşılması güç anlamlardır. Ve bu düşünce tanıdık şeyleri alışılmadık bir biçim ve usulde ifade etmeyi ve böylece algı sürecini zorlaştırmayı ve uzatmayı savunan yabancılaştırma tekniğini hatırlatmaktadır.

Kendilerini alışılmamış anlamlar bulmaya adayan bu şairler zaman zaman kendi anlayışlarına uymayan şairleri ve şiir okurlarını yermektedir:

Havf ider sarf itmege endîşesin dahı kibâr

Sâdece eş'âr arar dikkatli mazmûn istemez (Sâmî G.48/7)

Sâmînnin dile getirdiği bu düşünce Hint üslubu etkisinde şiir yazan diğer şairlerin de paylaştığı bir anlayıştır. Yani bir şiirdeki mazmun (örtülü anlam, nükte) okuru düşünceye sevketmeli, oradaki saklı anlamı bulmak için çaba sarf etmelidir.

\section{Defamiliarization}

Ma'nâ-yı bîgâne ile Rus formalistlerin savundukları defamiliarization (yabancılaştırma) arasında hem ismen hem de mahiyet itibariyle ciddi benzerlikler dikkat çekicidir. Defamiliarization Rus formalistlerinden Shklovsky'nin (1893-1984) ileri sürdüğü ostranenie (yabancılaştırma) teriminin İngilizceye tercümesidir. Yabancılaştırma bilinen ve tanınan şeyleri yeni, tuhaf ve farklı hâle getirmektir (Cuddon 2013: 192). Sebk-i Hindî terminolojisiyle ifade edecek olursak âşinâ olunan şeyleri bîgâne bir surette sunmaktır.

Shklovsky'ye göre alışkanlıkla malul olan normal algılarımız otomatikleşir ve şuursuz bir hâl alır. Mesela gündelik konuşmada ifadeleri ve kelimeleri eksik ve yarım bırakırız. Shklovsky bu durumu, sıradan algılarımızı etkileyen cebirselleştirme (algebraization) sürecinin bir yan etkisi olarak görür. Cebirselleştirme süreci nesneleri bir formül gibi sadece göze çarpan bir özelliğe veya işleve indirger. Shklovsky Tolstoy'dan şu alıntıyı yapar: "Çoğu insanın bütün hayat karmaşası bilinçsizce devam eder... adeta bu tür hayatlar hiç olmamış gibi.” Çünkü alışkanlıklar her şeyi kemirir. Sanat ise hayata dair hissiyatı onarma imkânını verir. Sanatın tekniği nesneleri tanınmaz kılmak, biçimleri zorlaştırmak, algı genişliğini ve zorluğunu artırmaktır. Çünkü algılama süreci bizzat estetik bir hasıladır ve uzaması 
gerekir. Sanat, bir nesnedeki mahareti ve fevkaladeliği tecrübe etmenin bir yoludur; nesne önemli değildir (Habib 2005: 603-604).

\section{Ma'nâ-yı bîgâne ve defamiliarization}

Hint üslubu şairlerinin ma'nâ-yı bîgâne, ma'nâ-yı dûr, ma'nâ-yı pîçîde gibi kavramlarla dile getirdikleri şiir anlayışları ve bu anlayışın şiirdeki tezahürleriyle yabancılaştırma yöntemi arasındaki benzerlikler son dönemde araştırmacıların dikkatini çekmiştir (bkz. Hakcû \& Rızâyî 1397; Üskûyî 1383). Her üç araştırmacı Hint üslubunda yabancılaştırma (Farsçada bîgâne-sâzî, garîb-sâzî [= yabancılaştırma], âşinâŷ́-zodâŷ̂ [= aşinalı̆̆ı silme]) olgusunu Sâib-i Tebrîzînnin şiirleri üzerinden incelemiştir. Hakcû ve Rızâyînnin çalışması yabancılaştırma yollarından biri olarak "istiâre-i îhâmî-yi kinâyeî-yi hemrâh bâteşbîh" (ekseninde kinayenin olduğu teşbih, iham ve istiarenin iç içe geçtiği bir yapı) diye adlandırılan bir anlam yumağını ele alır. Üskûyî ise yabancılaştırma olgusunu altı maddede ele almıştır: 1. Kinayelerin ve mecazî terkip ve ıstılahların gerçek manalarıyla kullanılması. 2. Yeni ıstılah ve terkipler. 3. Kelimesel ve dilbilgisel tahrif. 4. Sâib’in telmihleri yabancılaştırması ve îcâz kudreti 5. Mantıksal yabancılaştırma (paradoks) 6. Yeniden tarif.

Bu çalışmada Üskûyînin tasnifine ilaveten girift manalar (ma'nâ-yı pîçîde), hiss-âmizî (his karmaşası, çoklu duyulama, duyumlar arası geçiş) ve Türkçede yabancılaştırıcı etkisi daha çok hissedilen "tetâbu-ı izâfât ve Farsça ifade kalıpları" maddeleri ilave edilmiştir. Farsçadaki ulaşabildiğimiz çalışmalar Sâib-i Tebrîzînnin gazelleriyle sinırlıyken bu çalışmada muhtelif Türk ve Fars şairlerinin şiirlerine müracat edilmiştir.

Türkçede Sebk-i Hindî üslubu konusunda en kapsamlı çalışma İsrafil Babacan'a aittir (Babacan 2010). Babacan Sebk-i Hindî’yi menşe, Türk ve Fars şiirindeki durumu, dil, şekil ve mana özellikleri yönünden incelerken bizim çalışmamız Sebk-i Hindî’nin yabancılaştırıcı özelliklerine hasredilmiştir. Bilhassa telmih ve kinayelerdeki farklılıklar daha detaylı incelenmeye çalışılmıştır. Ayrıca bazı örneklerin tahlili vasıtasıyla bu şiir tarzının daha iyi tanınmasına ve anlaşılmasına katkı sunmayı hedeflemektedir.

\section{Yöntem}

İncelemeye esas teşkil eden veriler Türk şairlerden Fehîm-i Kadîm (ö. 1647), Şehrî (ö. 1660), Nâilî-i Kadîm (ö. 1666), Neşâtî (ö. 1674), Nâbî (ö. 1712), Arpaemînizâde Sâmî (ö. 1734), Şeyh Gâlib (ö. 1799)'in altmış beşer gazelinin; Farsça yazan şairlerden ise Tâlib-i Âmulî (ö. 1626), Kelîm-i Kâşânî (ö. 1651), Sâibi Tebrîzî (ö. 1676), Şevket-i Buhârî (ö. 1700), Bîdil-i Dehlevî (ö. 1720)'nin kırkar gazelinin taranmasıyla elde edilmiştir. Ayrıca bazı kelime ve terkipler için 140 Türkçe divandan ve 70 Farsça divandan oluşan veri bankası² taranmış, bunun sonucunda gerekli görülen beyitler çalışmaya dâhil edilmiştir.

\section{Girift manalar (ma'nâ-yı pîçîde)}

Hint üslubu şairlerinin bîgâne manalar peşinde olmaları bazı anlaşılması güç kavram, mısra veya beyitlerin ortaya çıkmasına sebep olmuştur. Anlaşılma güçlüğü olan beyitler irad etme konusunda Bîdili Dehlevî, Şevket-i Buhârî gibi bazı şairler (Hint veya ifrâtiyyun kolu) aşırıya giderken Örfî-i Şîrâzî, Kelîm-i Kâşânî, Tâlib-i Âmulî, Sâib-i Tebrîzî gibi bazı şairler (İsfahan veya i’tidâliyyûn kolu) ise daha

2 Bu veri bankası şunlardan oluşmaktadır: Türkçe divanlar; Prof. Dr. Ahmet Atilla Şentürk'ün metin ambarı projesinde divanlar ve Kültür Bakanlığı e-kitap sayfasında yer alan divanlar, ayrıca tarafımızdan dijital ortama aktarılan Nâbî ve Fehîm-i Kadîm divanları. Farsça divanlar; ganjoor.net sayfasında yer alan divanlar ve tarafımızdan dijital ortama aktarılan Baba Figânî, Feyzî-i Hindî, Tâlib-i Âmulî, Kelîm-i Kâşânî, Şevket-i Buhârî, Hazîn-i Lâhicî, Ganî-yi Keşmîrî divanları. 
mutedil bir yol izlemişlerdir. Klasik belagatte kusur sayılan ve ta'kîd diye adlandırılan bu husus Hint üslubu şairlerinin kaçındığı bir durum değildir. Örneğin Şeyh Gâlib "Düşüncemiz girift manaya dolaşıktır" mealindeki bir ifadeyle meseleye bakışını dile getirir:

Vasf-ı zülf ü turre-i âteş-ruhândır pîşemiz

Ma'nî-i pîçîdeye pîçîdedir endîşemiz (Gâlib G.113/2)

Sâib’in aşă̆ıdaki beytinde de benzer bir yaklaşım söz konusudur:

از براى موشكافان در رك هر سنبلى / معنيى بيجيده جون موى كمر دارد بهار (Sâib G.4583/9)

(Kılı kırk yaranlar için sünbülün her damarında baharın, kıl gibi ince beli andıran, dolaşı [= girift] manası vardır.)

Başkaları tarafından beğeni görmese de bu mananın idrak edilmesindeki lezzet şair için yeterledir:

$$
\text { لذا لذت ادر معنى دلكثاى ما بس است / رزق ما كر از سخن تحسين نباثد كَ مباش (Sâib G.4883/5) }
$$

(Bize gönül açan mananın idrakindeki lezzet kâfidir. Eğer övgü dolu sözlerden nasibimiz olmazsa gam değil.)

Bu şiir anlayışının neticesinde manasına nüfuzda güçlük çekilen mısra ve beyitler ortaya çıkmış ve bazı beyitlerde ne denilmek istendiğine dair tartışmalar on yllar boyunca devam etmiştir. Örneğin Arpaemînizâde Sâmî’nin aşağıdaki beyti ilk defa Müstakîmzâde Süleymân Sadeddin Efendi (ö. 1788) tarafından şerh edilmiş ( $1180=1766 / 1767)$, daha sonra Bursalı Mehmet Tahir (ö. 1925), Ferid Kam (ö. 1944), Tahir Olgun (ö. 1951), Veled Çelebi İzbudak (ö. 1953), Talat Onay (ö. 1956), A. H. Tanpinar (ö. 1962), Ali Nihad Tarlan (ö. 1978) gibi birçok isim beytin ikinci mısrayyla ilgili muhtelif fikirler beyan etmiştir (Kutlar 2009).

Hâzır ol bezm-i mükâfâta eyâ mest-i gurûr

Rahne-i seng-i siyeh penbe-i mînâdandır (Sâmî G.34/3)

(Ey gurur sarhoşu, mükâfat meclisine hazır ol. [Zira] siyah taşın parçalanması şarap şişesindeki pamuktandır.)

Beyitte sözdizimsel bir problem veya bilinmeyen bir kelime yahut terkip olmamakla beraber, ikinci mısrada dile getirilen "siyah taşın parçalanması" ile "şarap şişesinin ağzındaki pamuk" arasındaki münasebet çok açık değildir (ta’kîd-i ma’nevî).

Şeyh Gâlib’in aşağıdaki beytindeki muğlaklığın kaynağı ise klasik şiirde daha önce rastlanmayan "tûti-i zenbûr" terkibidir:

Gûyâ hayâl-i hatt-ı lebünle müjemde hûn

Bâg-1 vefâda tûtî-i zenbûrdur bana (Gâlib G.1/6)

(Dudağının ayva tüyleriyle kirpiğimdeki kan sanki vefa bağında benim için tûtî-i zenbûr'dur.)

Tûti-i zenbûr terkibi geveze papağan (Tarlan 1990: 113-114), arı kuşu (Şentürk 2016: 344-345), dudağın çekiciliğiyle ayva tüylerinin iticiliğini birlikte dile getiren bir tezad hayali (Gürer 2000: 104) ve bir çeşit çiçek (Kaçar 2018: 57-58) gibi birbirinden farklı anlamlarla yorumlanmıştır. 
Bu beyitlerle ilgili farklı yorumları burada tekrar aktarmak yerine Sâib’in ve Nâbî̀nin birer beytini ele alacağız. Aşağıdaki beyitlerde Şeyh Gâlib ve Sâmî’nin beyitleri kadar olmasa da bir ölçüde müphemlik bulunmaktadır.

$$
\text { نيست از تيغ زبان موج برو ايیى مر / خامشى جون آب كو هر حرز طوفان من است (Sâib G.1082/8) }
$$

(Dalganın dil kılıcından korkumuz yoktur. Suskunluk, inci suyu gibi [olan] benim tufanımın mahfazası ve muskasıdır. / Veya: Suskunluk, inci suyu gibi benim tufan mahfazamdır, beni tufandan korur.)

Zihnin kolay intikal edemeyeceği, uzak çağrışımlı, dolaylı, yeni veya nadir bazı somutlaştırmalar vasıtasıyla alışılmamış bağdaştırmalar kurmak Sebk-i Hindî şairlerinin çokça başvurduğu bir usuldür. $\mathrm{Bu}$ beyitte birçok benzetme yapılmış ve bunlara bağlı olarak iç içe geçmiş bir hayal örgüsüyle karşılaşıyoruz. Ayrıca ikinci beyitte cümle yapısından kaynaklanan bir anlam karışıklığı da bulunmaktadır. Beyti görünen unsurlarıyla tahlil ettiğimizde şu tespitleri yapabiliriz:

1. Dil kılıca benzetiliyor (tîg-ı zebân). 2. "Suskunluk benim hırz-ı tûfânımdır" ifadesi iki şekilde anlaşılmaya müsaitttir: a. hırz-ı tûfân terkibini izâfet-i lâmiyye (aidiyet bildiren belirtili isim tamlaması) olarak kabul edersek: Suskunluk benim tufanımın muskasıdır. b. İzâfet-i beyâniyye (bir şeyin cinsini bildiren belirtisiz isim tamlaması) olarak düşünürsek: Suskunluk benim tufan muskamdır (Beni tufandan koruyan muskadır). 3. Şair, suskunluğu veya tufan mahfazasını sedefin içinde inci olmayı bekleyen suya benzetiyor olabilir (hâmuşî çün âb-1 gevher veya çün âb-1 gevher hırz-ı tûfân). Oysa suskunluğun mahfazaya (ve dolaylı olarak sedefe) benzetilmesi daha uyumlu olacaktır. Fakat bu durumda âb-ı gevher gibi olan nedir?

$\mathrm{Bu}$ beyitte asıl vurgu suskunluğun dış etkilerden koruyucu olduğu düşüncesi üzerinedir. Şair bu düşünceyi tufan, inci, dalga ve ismen zikredilmeyen sedef unsurlarıyla oluşturduğu bir hayalle desteklemektedir. Bu hayale göre ağzın kapalı hâli sedefi, dişler ise inciyi çağrıştırır. Bu somut benzerlik ve çağrışımın dışında suskunluk sedef vazifesini görür ve şairin inciyi andıran benliğini hadiselerin tufanından muhafaza etmektedir, tıpkı inci olma aşamasındaki suyu yani âb-ı gevheri sedefin muhafaza ettiği gibi. Bu durumda âb-ı gevher gibi olan "ben" yani şairdir. O hâlde ikinci mısraın anlamı şöyle olabilir:

(Suskunluk [sedefin] inci suyu[nu muhafaza ettiği] gibi benim tufan[a karşı] muskamdır.)

Nitekim yukarıda kapalı istiare yoluyla kurulan sedef - suskunluk benzerliği aşă̆ıdaki beyitte açıkça dile getirilmiştir:

$$
\text { طرفى از دريا نبست از يو ج كويى ها حباب / از خموشى جون صدف شد آب كو هر رزق ما Sâib G.256/6) }
$$

(Kabarcık boş sözlerle denizden bir şey hasıl edemedi. Suskunluk sayesinde sedef gibi gevher suyu bizim rızkımız oldu.)

Nâbî’nin “şevkinin alnını kurtuluş yoluna ayak yap. Kirpiklerini Arafât’nn tozuna süpürge yap” mealindeki beytinde bir secde ve namaz mazmunu soyut kavramların arkasına ustalıkla gizlenmiştir:

Pîşânî-i şevkun kadem-i râh-ı necât it

Müjgânunı cârûb-ı gubâr-1 'Arafât it (Nâbî G.27/1)

Şevk ve necât kavramları pîşânî (alın) ve râh (yol) kelimeleriyle terkip yapılarak somutlaştırılırken secde eylemi ise bu terkipler marifetiyle soyut bir mahiyet kazanmıştır. Alnın ayak yapılması düşüncesi Hint 
üslubu şairlerinin sevdiği türden bir tezat oluşturur. Necât (kurtuluş) kelimesi pîşân̂ (alın) ile birlikte düşünüldüğünde secde mazmununa ulaşmaya yardımcı bir karinedir (hayyâ ale'l-felâh = haydi kurtuluşa). Sonraki beyitte aynı hayal devam ettirilmektedir. Bu kez kaşlar birer ayak gibi tasavvur edilmiştir ve alnın Tanrı yolunu katetmesi kaşların adımlarıyla gerçekleşecektir:

Tayy eyle cebînünle reh-i kûy-ı Hudâyı

Ebrûlarun âmâde-i feyz-i hatavât it (Nâbî G.27/2)

\section{Yeni mazmunlar}

Hint üslubu şairleri için yeni anlam ilişkileri keşfetmek, yeni çağrışım ağları ve mazmunlar yaratmak önemli bir husustur. Yeni bir mazmuna ulaşmak için başlıca iki yol izlenmiştir:

a. Eski bir mazmunun yeni anlam ilişkileri içerisinde, farklı bir bakış açısıyla sunulması (yeniden tarif). Şeyh Gâlib’in "Ey Gâlib, yeşil izli [= neşeli, mutlu, suya kanmış] kalemim hayat bahşeden Hızır gibi geçtiği eski yerleri yeni ve taze kılar” mealindeki beyti bu anlayışı yansıtmaktadır:

Gâlib zemîn-i köhneyi Hızr-ı hayât-veş

Geçdikçe kilk-i sebz-peyim nev-zemîn eder (Gâlib G.62/8)

b. Özellikle gündelik hayata dayanan gözlem ve tecrübelerin şiire aktarılması yoluyla yeni hayallere ulaşıldığını görüyoruz. Şeyh Gâlib "Düşüncemiz söylenmemiş manaya gönül vermiştir” ifadesiyle anlayışı dile getirmektedir:

Dâ'ima fikr-i dehân-ı dil-rübâdır pîşemiz

Ma'nî-i nâ-güfteye dil-dâdedir endîşemiz (Gâlib G.113/1)

\subsection{Yeniden tarif}

Ceylanın ürkekliği ve avlanmasının zorluğu eskiden beri şiire konu olmuştur. Sâib bu eski manayı farklı bir bakış açısıyla ele alarak yeni bir hayale ulaşmıştır:

$$
\text { آهوان از تنگ ميداني به من كثتند رام / بس كه از شور جنونم دشت مالامال بود (Sâib, G.2626/5) }
$$

(Divaneliğimin coşkusuyla çöl öyle doluydu ki ceylanlar meydanın darlı̆̆ sebebiyle bana ram olurlardı.)

Kadehin hırka altında saklanması eski bir manadır. Ancak bunun bulut ve şimşeğe teşbih edilerek izah edilmesi yeni bir mazmundur:

$$
\text { صائب لباس برق نكردد حجاب ابر / تا جند زير خرقه توان داشت شيشه (Sâib G.742/8) }
$$

(Ey Sâib, bulut örtüsü şimşeğe elbise olmaz. Daha ne zamana kadar hırkanın altında kadehi saklayacaksın.)

Klasik şiirde gül ve bülbül mebzul miktarda yer alır. Ancak Şevket’in aşağıdaki beytinde karşımıza çıkan "kanadından baharın kanı damlayan bülbül” imgesi alışılmamış yeni ve çarpıcı bir hayaldir:

$$
\text { عندليبم مى جكه از بال من خون بهار / رشتهُ كل دسته كردد دام دست و بإى من (Şevket K.9/53) }
$$

([Ben öyle bir] bülbülüm ki kanadımdan baharın kanı damlar. Gül destesinin ipi benim elimin ve ayağımın tuzağı olur.)

$$
\text { از دماغ خامةُ من خون نخوت مى جكد / بس كه شد مست غرور از معنى غرّاى من (Şevket K.9/59) }
$$


(Kalemim benim parlak mânâmdan öyle gurur sarhoşu oldu ki burnundan kibir kanı damlıyor.)

Şeyh Gâlib’in uykuyu bileyi taşına benzettiği aşağıdaki beyti güzel ve ilginç bir örnektir:

Seng-i nişân-ı hâbda tîz eyler el-hazer

Tîg-ı nigâhı sanma girân-hâbdır bu şeb (Ş. Gâlib G.18/7)

Bakış keskinliği, bakışın hançere yahut kılıca benzetilmesi eskiden beri şairlerin dile getirdiği bir husustur. Ancak buradan hareketle uykunun bileyi taşına benzetilmesi ve uykudaki sevgilinin göz kılıcını keskinleştirdiği hayali yeni bir benzetmedir.

Rikâb-âsâ basarlar pâların müjgânı-ı şîâna

Ta'alluk hârını anlar ki bîrûn eylemişlerdir (Şeyh Gâlib G.45/8)

(Dünya alakalarınının dikenini gönlünden atanlar, ayaklarını üzengi gibi arslanların kirpiklerine basarlar.)

Kaş klasik şiirde yay, mihrap ve köprüye benzetilir. Bunların hiçbiri olumsuz bir manada değildir. Ancak Nâbî sevgilinin kaşını köprüye benzetirken bunun mihraba göre bir tenzîl-i rütbe olduğunu söyleyerek farklı bir bakış açısı getirir:

Leşker-i hat ebruvânın itdi pâ-mâl-i gubâr

İndi püller pâyesine bir zamân mihrâb iken (Nâbî G.605/3)

(Ayva tüyü ordusu kaşlarını toz içinde bıraktı. [O kaşlar] bir zamanlar mihrap iken köprü rütbesine indi.)

Diş klasik şiirde ilk defa Nâbî tarafindan kullanılmamıştır. Fakat bunun birbiriyle savaşmak için karşı karşıya saf bağlamış iki orduya benzetilmesi yeni bir hayaldir:

Lokma sermâye-i gavgâ vü fesâd oldugına

Anlar ehl-i dil olanlar saf-ı dendânından (Nâbî G.635/6)

(Gönül ehli olanlar dişlerinin [karşılıklı] saf bağlamasından lokmanın kavga ve fesat sermayesi olduğunu anlar.)

Cân-bâz ve havf ü recâ (korku ve ümit) çeşitli vesilelerle divan şiirine konu olmuştur. Fakat havf ü recâ düşüncesinin ip üzerinde düşmeden yürümeye çalışan bir cambazla anlatılması, cambazdan havf ü recâ fikrine varılması yeni bir hayaldir:

Bâlâ-yı rîsmânda cân-bâza kıl nazar

Havf ü recânun eyle temâş̧â temessülin (Nâbî G.637/2)

\subsection{Yeni hayal}

Soyut fikir ve kavramlarla gündelik hayata ait eşya ve hadiseler arasında münasebetler kurmak Hint üslubu şairlerinde çok rastlanan bir üslup özelliğidir. Edebiyatta benzetme her zaman olagelmişse de klasik şiirin yerleşmiş teşbih ve istiarelerinin dışına çıkılması mühim bir yeniliktir.

Bîdil ihtiyarlığı sabaha benzettiği aşağıdaki beyitte ağarmış saçları ise kefen kumaşının atkı ve çözgü iplikleri (kumaşın dokusunu oluşturan yatay ve dikey ipler) olarak nitelemektedir: 


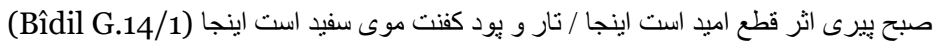

(İhtiyarlık sabahı ümidi kesmenin işaretidir burada. Beyaz saç telleri kefeninin atkı ve çözgü ipleridir burada.)

Sâib divanelik, özgürlük ve kendinden geçme gibi hâlleri ve kavramları yine gündelik hayattan aldığı unsurlarla izah ediyor:

$$
\text { طوق زنجير جنون كار كريبان مى كند / جامه مار اكريبان كرنباشد كو مباش (Sâib G.4883) }
$$

(Divanelik zincirinin halkası yaka hükmündedir. Bizim elbisemizin yakası olmazsa olmasın.)

مركب آز ادكان تخت روان بيخودى است / توسن كَدون به فرمان كر نباشد كَ مباش (Sâib G.4880/7)

(Özgür insanların merkebi kendinden geçme taht-ı revanıdır. Feleğin dik başlı atı bize itaat etmezse etmesin.)

همجو آن ماهى كه در آتش فتد ناكه ز آب / ميطعم در خاك آن ساعت كه مى در جام نيست (Sâib G.215/4)

(Tıpkı sudan ateşe ansızın düşen balık gibi, kadehte şarap olmadığı anda yerde çırpınıyorum.)

Türk şiirinde de şairler gündelik hayata dair gözlemlerini şiirlerine yansıtmışlar, bunlarla yeni imgeler oluşturmuşlardır. Nâbî’nin "Yâ Rab, 'sevgilinin çene çukuruna kimin eli değdi?' diye elimi fikir çenesine sütun eyleme” mealindeki beytinde elini çenesine koyup düşüncelere dalan bir insan mazmunu vardır:

Engüşti kimün değdi diyü gabgab-ı yâre

Destüm zenah-ı fikre sütûn eyleme yâ Rab (Nâbî G.14/2)

Şeyh Gâlib dilencilikle ile şöhret peşinde olmak arasında ilginç bir benzerlik ve zıtlık kurar. Her ikisi de başkalarından bir şey talep etmektedir. Fakat dilenci elini açar, şöhret isteyen ise başkasının elini öper. Dolayısıyla dilencinin avuç içi yukarı dönüktür, öpülen elin ise avucu aşağı dönüktür:

Olup şöhret-talebler dest-bûs-ı halka hâcetmend

Kef-i deryûzeyi gûyâ digergûn eylemişlerdir (Şeyh Gâlib g.45/7)

Diğer dikkat çeken örnekleri günümüz Türkçesiyle vermek yeterli olacaktır:

Bir bâgda kim menzil ide mahmil-i nâlem

Hep beyza-ı murgânı figân-ı ceres eyler (Fehîm-i Kadîm g.57/5)

(İnlememin taht-ı revanının konakladığı (yani inlememin dindiği) bir bağda, bütün kuş yumurtaları [göç habercisi] çan gibi [tekrar inlemem için] feryat eyler.)

Dil-şikestem ol kadar kim şîşe-i sâ'at-misâl

Zahmum içre sûde-i elmâs tûde tûdedür (Fehîm-i Kadîm G.68/3)

(Saat [ = kum saati] camı gibi gönlüm öyle kırık ki yaramın içinde elmas kırıntıları yığın yığındır.)

Hep biz dahı dullâb-ı ümîde sarılurduk

Âb olsa eger ka'r-ı çeh-i tûl-ı emelde (Nâbî G.699/2)

(Eğer tükenmez arzu kuyusunun dibinde su olsaydı biz de ümit dolabına sarılırdık.)

\section{Telmihlerde yenilik, kapalılık ve îcâz}

Telmih öteden beri klasik şiirde mühim bir yer tutsa da Sebk-i Hindî şairlerinin orijinalliğe (ma’nâ-yı bîgâne), kapalılığa (ma’nâ-yı pîçîde, ma’nâ-yı dûr) ve az sözle çok şey anlatmaya (îcâz) verdikleri önem telmih anlayışlarına da yansımıştır. 


\subsection{Orijinallik ve yeni bakış açısı}

Sebk-i Hindî şairleri telmihte alışılmışlı̆̆ı aşmak için muhtelif yollara başvurmuşlardır. Herkesin bildiği bir hadisenin bilinmeyen, daha önce değinilmeyen bir yönüne işaret etmek veya onu yeni bir hayalle sunmak bunlardan biridir.

Vahdet-i vücûd akidesine bağlı olan Hallac-ı Mansûr'un Ene'l-Hak (ben Hakk'ım) demesi ve bundan dolayı küfürle itham edilip katledilmesi klasik şiirimizde ve tasavvvuf literatüründe yerini almış, kendsine şehîd-i aşk payesi verilmiş ve sevgili uğruna kendini feda etmenin timsali olmuştur. Doğal olarak klasik şiirde bu hadiseye çokça telmih yapılmıştır. Ancak Şeyh Gâlib bu hadiseye telmih yaparken Mansûr'un bir sözünü zikretmiş ve böylelikle eski şairlerin bahse konu etmediği bir noktayı öne çıkarmıştır:

Vuzû-yı aşka hûn lâzım demiş ber-dâr iken Mansûr

Bu kurbiyyet ziyâdât-ı nevâfilden zuhûr eyler (Gâlib G.49/4)

Vuzû-yı aşka hûn lâzımdır (aşk abdestine kan lazımdır) ifadesi paradoksal bir düşüncedir. Zira kan dinî yönden necis sayılır ve bununla abdest almak bir yana hem abdesti bozar hem de namazın şartlarını ihlal eder.

Şevket aşağıdaki beyitte ölüm çölüne benzettiği istiğnanın ebedî hayat bahşettiğini ve âb-ı hayata ulaşma arzusunun ise kendisi için İskender seddi olduğunu dile getirmektedir.

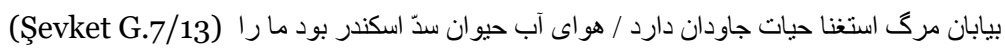

(İstiğnanın ölüm çölü ebedî hayat bahşeder. Âb-ı hayat hevesi bizim için sedd-i İskenderdir.)

Bu beyitte Hint üslubu şairlerinde rastladığımız birden fazla hususiyeti görebiliriz. 1 - İskender'e dair iki farklı hususa telmihte bulunmuş (Ye'cûc ve Me'cûc'a karşı sed inşa etmesi ve Hızır'ın rehberliğinde âb1 hayâtı araması), bunları ustalıkla aynı hayal unsuru içinde kaynaştırmış ve zengin çağrışımlara yol açmıştır (îcâz). 2 - Âb-ı hayata ulaşma arzusunun sedd-i İskender olarak yorumlanması yeni bir bakış açısıdır (ma’nâ-yı bîgâne, yeni mana ve hayal inceliği). 3 - Ölüm çölünün ebedîlik bahşetmesi (Paradoksal düşünce).

$$
\text { صاحب آيينه نتوان كثت بىقطع نفس / بكذرد از زندكى تا خضر ، سكندر شود (Bîdil G.1532/10) }
$$

(Nefesini kesmeyen [Hızır] ayna sahibi [İskender] olamaz. Hızır, hayattan vezgeçtiği zaman İskender olur.)

Klasik şiirde Hızır âb-ı hayâta ulaştığı için yerilen değil gıpta edilen bir şahsiyettir ve İskender'e üstün tutulur. Zira İskender âb-ı hayatı istemesine rağmen ona ulaşamamıştır. Bîdil ise herkesçe bilinen ve klasik şiirde yüzlerce defa bahsi geçen Hızır - İskender kıssasına aynı unsurları kullanarak (âb-ı hayât, ayna) fakat farklı bir bakış açısıyla telmihte bulunmaktadır.

Aşă̆ıdaki iki beyitte Hızır vefasızlık, merhametsizlik (16/8) ve hatta nankörlük (1539/3) timsali olarak karşımıza çıkar:

$$
\text { جشم دلسوزى مدار از همر هان روز سياه / كز سكندر خضر مى نوشد نهانى آب را (Sâib G.16/8) }
$$

(Kara günde [= zulmet] yoldaşlarından [= Hızır] merhamet umma. Zira Hızır İskender'den gizli su [= âb-ı hayât ] içer.) 
به سكندر ندهد قطره آبى، هر جند / خضر سيراب ز اقبال سكندر شده است (Sâib 1539/3)

(Hızır her ne kadar İskender'in ikbaliyle suya kansa da İskender'e bir damla su vermez.)

Hint üslubunda rastladığımız ifrat derecesinde mübalağaya yer verme hususiyeti telmihlere de yansımıştır. Bunu yaparken en sık kullanılan yöntem ise telmihte bulunulan şahsiyete zıt bir özellik izafe etmektir. Örneğin ilm-i ledün sahibi olan ve yol göstericilik timsali olan Hızır Fehîm'in mısralarında kaybolabilir (II/1/6) veya yol kesici (16/8) olarak karşımıza çıkabilir. Keza şairin göz yaşları, tufan için bile bir afete dönüşebilir (127/1).

Hızr-ı hidâyet eylese ta'yîn menzilüm

Hızr ile menzil ikisi de güm-sürâg olur (Fehîm Terkîb-i B.II/1/6)

Cân-ı hasret-zedeyüz 'âzim-i şehr-i hırmân

Hızr-1 tevfík bize reh-zen olursa ne aceb (Fehîm G.16/8)

Dîde-i Nûh'uz ki âşûb-ı cihândur giryemüz

Belki tûfâna dahi âfet-resândur giryemüz (Fehîm G.127/1)

Şeyh Gâlib aşağıdaki beyitte Mansûr'un boğazını neye benzetir. Şair ney ile boğaz benzerliği kurduktan sonra telmihte bulunulan hikâyenin diğer unsurlarını buna göre yeniden düzenler. Mansur'un asıldığı darağacı bir makamdır [rütbe, müzik makamı] ve aşk nağmesiyle bu hâle uygun şarkılar söylemektedir:

Nevâ-yı aşk ile nây-ı gelûsu Mansûrun

Makâm-ı dâra münâsib terâneler söyler (Şeyh Gâlib G.51/5)

Aşağıdaki beyitte ise şair önce "hakikat Mısrı'nın saltanatı" tabiriyle bir somutlaştırma yapar. Aslında böylelikle kıssanın diğer unsurları soyut bir mahiyet kazanmıştır. Bu hakikat Mısrı'nın Yûsuf'u nağme, kuyusu ise neyin içidir:

Dem urur saltanat-ı Mısr-ı hakîkatdan Kays

Yûsuf-1 nagmeye çâh olsa siyeh-hâne-i ney (Gâlib G.304/2)

Leyla ve Mecnûn hikâyesinin kahramanı olan Kays aşkı sebebiyle kendini sahralara vurmuş ve aklını yitirmiş bir karakterdir. Böyle olmasına rağmen ney üflenmeye başlayınca [ = dem urmak] Kays'ın Mısır saltanatından dem vurması ilk bakışta Kays'ın bilinen özellikleriyle bir tezat oluşturur. Ama diğer yandan bu "hakikat Mısrı'nın saltanatı"dır, dünya saltanatı değildir.

\section{2. Îcâz}

Lugat manası "sözü kısaltmak" olan îcâz îcâz-ı hazf (eksiltme ile yapılan îcâz) ve îcâz-ı kısar (az ve öz söz söyleyerek yapılan îcâz) olmak üzere iki kısma ayrılır (Saraç 2017: 73-75). Burada dikkat çekmek istediğimiz az sözle çok mana ifade etme türündeki îcâzdır.

Hint üslubu şairleri bazı hadiseleri birbiriyle mezcetmiş, iki farklı hadiseye ait unsurları veya aynı hadiseye ait farklı mazmunları birbiriyle bütünleştirmeleridir. Fakat burada kastedilen aynı beyitte iki farklı hadiseye veya şahsa telmihte bulunulması değildir. Mesela Ebû Saîd Ebu'l-Hayr (ö. 1049) bir rubâisinde Tûr ve Mansûr'dan bahsetmektedir. Ama bunlar birbirinden bağımsız iki unsur olarak yer almıştır: 
اى شعلةُ طور طور بِر نور از تو /وى مست به نيم جرعه منصور از تو (Ebû'l-Hayr R.574/2)

(Ey Tûr'un ateşi, Tûr senin vesilenle nur ile dolmuştur ve Mansûr senin sayende yarım cur'ayla [= şarap tortusu] sarhoş olmuştur.)

Hint üslubu şairleri ise farklı mazmunları veya bu mazmunlara ait unsurları iç içe geçirerek; girift, zengin ve renkli anlamlara ulaşmışlardır. Sâib aşağıdaki beyitte Mansûr'un asıldığı darağacının kuru dallarıyla Tûr dağında Tanrı'nın tecellisiyle yanan ağaç arasında bir münasebet kurar:

$$
\text { سر هر كس كه كرم از باده منصور مى كردد / به جشمش جوب خشك دار نخل طور مى كردد (Sâib G.2842/1) }
$$

(Mansûr'un şarabıyla başı dönen herkesin gözünde darağacının kuru tahtası Tûr ağacı olur.)

Aşă̆ıdaki beyitlerde de aynı bakış açısı görülmektedir:

$$
\text { برق تجلى ونفس اهل دل يكى است / منصور دار راشجر طور مى كند (Sâib G.4186/4) }
$$

(Tecellî şimşeğiyle gönül ehlinin nefesi aynıdır. Mansûr darağacını Tûr ağacı yapar.)

كر حق نكرى لايق منصور نباثد / دارى كه زجوب شجر طور نباشد (Kelîm-i Kâşânî G.195/1)

(Eğer doğru bakarsan Tûr ağacının dalından yapılmayan bir darağacı Mansûr’a layık olmaz.)

$$
\text { جه ذوق از عرش دارد فرش طورم / سر منصور و يُاى موسيم نيست (Tâlib-i Âmulî G.159/8) }
$$

(Mansûr'un başı ve Mûsâ'nın ayağı yok [iken] Tûr'umun zemini arştan ne tad alır.)

Türk şairleri de bu tarz telmihleri çokça kullanmışlardır:

Mansûr-1 "Ene'l-Hak”-zen-i vâdi-i Kelîm'em

Ser-tâ-be-kadem nûr-ı Hudâ nârı ne bilsün (Fehîm-i Kadîm G.6/3)

Aşk âteş-i tecellî-i Mansûrdur bana

Her çûb-ı dâr bir şecer-i Tûrdur bana (Şeyh Gâlib G.1/1)

Kühsâr-1 “ene'l-Hakka” kadem basmadan âdem

'Aks eyler idi na'ra-i Mansûr-ı tecellî (Neccâr-zâde G.152/4)

Sâib’in aşağıdaki beyitlerde âb-ı hayat ile İskender’in aynası ve seddi arasında kurduğu münasebet ve burada ortaya çlkan hayal ve anlam yoğunluğu da bir îcâz örneğidir:

$$
\text { خالك زن در جشم خودبينى كه از آب حيات / سد اسكندر به جز آيينه اقبال نيست (Sâib G.1299/2) }
$$

(Hodbinlik [= kendini görme = bencillik ve kibir] gözüne toprak savur. Zira âb-1 hayâta ikbal aynasından başka İskender seddi yoktur.)

$$
\text { خودبينى از حيات ابد سنع راه توست / از آب خضر ، آينه سد سكندرست (Sâib G.1883/7) }
$$

(Hodbinlik senin ebedî hayata ulaşma yolundaki taştır. Ayna Hızır’n suyu [önünde] İskender seddidir.)

$$
\text { زنح ظلمت بود از آب زندكانى قسمتش / تا سكندر روى در آيينه اقبال داشت (Sâib G.1331/3) }
$$

(İskender’in yüzü ikbal aynasında olduğu için âb-ı hayattan nasibi [sadece] zulmet pası olur.)

\subsection{Kapalılık ve aşırı hayalcilik}

Şiirin zihnîleşmesi, yeni ve alışılmamış manalar bulma çabası ve az sözle çok şey anlatma arzusu şiirde kapalılığı ve aşırı hayalciliği de beraberinde getirmiştir. Aslında bu durum ma'nâ-yı pîçîde (girif anlamlar) bahsinde ele alınan hususların telmihteki tezahüründen ibarettir. 
Sâib’in aşağıda aktardığımız beytinde aşırı hayalcilikten ve sözdizimi kaynaklı olmayan kısmî bir kapalılıktan söz edilebilir. Beyit, yeni bir hayal örgüsü sunulması sebebiyle çözülmeyi bekleyen anlam ilişkileri içermektedir.

$$
\text { تاج اقبال سكندر اين جنين لعلى نداشت / بيش ياجوج سخن سد خموشى بسته ايم (Sâib G.5434/4) }
$$

(İskender’in tacının böyle bir la'li [= parlak, kırmızı mücevher] yoktu. Söz Ye'cûc’unun önünde sükût seddi bağladık.)

Şair sözü Ye'cûc'e, sükûtu ise sedde benzetmekte ve İskender'in buna sahip olmadığını dile getirmektedir. Tacdaki olmadığı söylenen la'l ile sükût ve sed arasındaki münasebet ise şudur: Klasik şiirde kırmızı olması sebebiyle dudak la'le benzetilir. Beytin arka planında kapalı duran bir ağız ve "bağlanmış" (besteîm = bağladık) bir dudak imgesi vardır ve bu kapalı dudak şaire sedd-i İskender’i çağrıştırmaktadır.

Yûsuf-ı işkeste-bâle sor bu evc-i tâli'i

Murg-i bahtın sîlî-i ihvân-ı per pervâzıdır (Şeyh Gâlib, g.55/2)

Şeyh Gâlib’in bu beyti şöyle nesre çevrilebilir: "Bu talih zirvesini kanadı kırık Yûsufa sor. Kanat kardeşlerinin sillesi baht kuşunun uçuşudur.” Şaire göre Yûsuf (A.S.) uğradığı haksızlık ve karşılaştığı zorluklar sebebiyle kanadı kırık bir kuş gibidir. Kardeşlerinden gördüğü haksızlık ise tokat (sîlî = sille) olarak nitelendirilmiştir. Kardeşlerinin bu tokatıyla baht kuşunun kanat çırpışı birbirine benzemektedir (sîlî-i ihvân-ı per). Nihayet Hz. Yûsuf'un, kardeşlerinden yediği tokatla başlayan zorlu yolculuğu Mısır'a sultan olmasıyla neticelenmiş ve böylelikle sîlî-i ihvân onun kanadı olmuştur.

Sadâ-yı çâk gelür dahı ceyb-i Yûsuf'dan

Muhâl oldugıçün 'aşk-ı bî-hicâb ile bahs (Şehrî g.15/3)

(Utanmaz aşk ile söyleşmek muhal olduğu için Yûsuf'un gömleğinden yırtılma sesi gelir.)

Züleyhâ’nın Hz. Yûsuf'a kapıları kapatması, Hz. Yûsufun ondan kurtulmaya çalışırken gömleğinin yırtılması hadisesine telmihte bulunulmuştur. Fakat bu meşhur hadiseyi dile getiriş biçiminin beyitte bir muğlaklık oluşturduğu söylenebilir. Beyitte Züleyhâ yerine soyutlama yapılarak aşk-ı b̂̀-hicâb tabiri kullanılmıştır. Ayrıca yaşanılan arbede sonucu gömleğin yırtılması çok somut bir hadiseyken bu soyutlama sebebiyle belirsizlik artmıştır.

Çeşm-i şûhunla ben ol deştde Mecnûnum kim

Nigeh-i dîde-i âhûdur ana sâye-i bîd (Şeyh Gâlib, g.41/4)

(Şuh gözünle öyle bir çölün Mecnûnuyum ki ceylan gözünün bakışı ona söğüt gölgesidir.)

Sevgilinin şuh gözü âşık için çöldür ve âşık da böyle bir çölün Mecnûnudur. Bu aşk çölünde âşı̆̆a gölgesiyle serinlik veren söğü ağacı yerine bir ceylan gözlünün bakışıdır. Gözbebeğinin siyahlığı ile gölge arasındaki bu münasebet uzak bir çă̆rışımdır.

\section{Kinaye ve mecazların gerçek anlamda kullanılması}

"Kinaye bir sözü hakikî anlamının da kastedilmiş olması mümkün olmakla birlikte, hakikî anlamı dışında kullanmaktır" (Saraç 2001: 131). Kinayede zikredilen (lâzım) ve zikredilmeyen (melzûm) olmak üzere iki unsur bulunur ve zikredilen lâzımdan zikredilmeyen melzûma intikal edilmesi murad olunur. 
Mesela "falan, kılıcının bağı uzun biridir" denilmesinden (lâzım) onun uzun boylu biri olduğunu (melzûm) anlamamız beklenir (Sekkâkî 2017: 477).

Hint üslubunda girift ve ince hayallerle süslenmiş istiare, teşbih ve îhâmların mühim bir yeri vardır. Bu ince ve girift hayaller aynı zamanda edebî sanatların da birbirine mezcolduğu yapıları beraberinde getirmektedir. Cemiyetli beyitler söylemek eskiden de klasik şairlerin değer verdiği bir üslup özelliği olmakla birlikte Hint üslubunda bunlar hem daha karmaşı ve derinlikli bir yapıya bürünmüş, hem de daha çok üzerinde durulan bir husus olmuştur.

$\mathrm{Bu}$ girift ifade tarzının edebî sanatlardaki bir tezahürü de "istiâre-i îhâmî-yi kinâye" (ekseninde kinayenin olduğu îhâm ve istiarenin iç içe geçtiği bir yapı)'dir. Bu sanat bir şey hakkında kinayeli istiare yapmaktan ibarettir. Ama bu kinayenin tam veya yaklaşı gerçek sureti, yani onun lâzımî yönü, aslında o şeyde bulunur. Fakat melzûmun (kinayede murad edilen mecazî mana) o şeye yüklenmesi gerçek dünyadaki tecrübeye uymaz. Böylece geriye güçlü bir istiare kalır. Bu tarifi ayrıştırırsak aşağıdaki unsurlara ulaşırız (Hak-cû 1390: 258):

1. İstiare-i mekniyye

2. Kinaye

3. Gerçeklik

4. Îhâm（Hak-cû 1390: 259).

Aşağıdaki beyitlerde kinayeler sadece gerçek (lâzım) anlamında kullanılmıştır. Mecazi anlamları (melzûm) ise bu mısrala için uygun değildir:

$$
\text { صدق كيشان را فلك در خاك بنشاند جو تير / سرو اين كلثن به جرم راستى با در كلست (Bidil G.663/8) }
$$

(Felek doğru yolda olanları ok gibi yere diker. Bu gül bahçesinin servisinin ayağı doğruluk cürmü sebebiyle çamurdadır.)

1. Pâ-der-gil bûden (ayağı çamurda olmak) tabiri sıkıntıda olmaktan kinayedir.

2. Bunu istiare-i mekniyye yoluyla serviye nisbet etmiştir.

3. Ayağı çamurda olmak tabirinin gerçek sureti yaklaşık olarak servi için geçerlidir. Serviler genellikle su kenarında oldukları için ayağı (alt kısmı veya kökleri) çamurdadır.

4. "Servinin ayă̆ının çamurda olması" ifadesiyle pâ-der-gil tabirinin kinayeli anlamının irtibatı yoktur.

5. Kinayenin lâzımî ve melzûmî anlamlarının karşı karşıya gelmesinden îhâm ortaya çıkmaktadır.

$$
\text { يوسف كَنام من از مكر اخوان فارغ است / سر به جيب خويش بردن جاه كنعان من است (Sâib G.1082/13) }
$$

(Benim unutulmuş Yûsufum kardeşlerinin hilesinden fariğdir. Başı yakanın içine çekmek [derin düşüncelere dalmak] benim Ken'ân kuyumdur.)

Ser be-cîb-i hîş borden (başını kendi yakasının içine götürmek veya çekmek) ifadesi derin düşüncelere dalmak anlamında kullanılan bir tabirdir. Fakat bu beyitte Hz.Yûsuf un atıldığı kuyuya benzetilmesi sebebiyle tabirin mecazi anlamından daha ziyade gerçek anlamında kullanıldığını göstermektedir. Şair 
bu tabirin gerçek manasını alarak "yakası içine çekilmiş bir baş" figürüyle kuyu içindeki insanın etraftan tecrit edilmişliği arasında bir münasebet kurmuş ve burayı emniyetli bir yer olarak tasavvur etmiştir. Bu yaklaşım, Hint üslubu şairlerinin telmihleri farklı bakış açısıyla ele almasına da bir örnektir.

Sâib’in aşağıdaki beytinde ise önce kinayeli bir deyim kullanılıyor. Mısra ilk okunduğunda sadece mecazî anlam akla geliyor. Fakat diğer mısrada tamamen deyimin hakikî anlamıyla ilgili bir düşünceyle karılaşıyoruz:

$$
\text { اى كه مى لرزى به شمع دولت بيدار خويش / كرد خود فانوسى از دست دعا مى بايدت (Sâib G.934/14) }
$$

(Ey kendi uyanık bahtının mumu üstüne titreyen! Kendi etrafına duaya kaldırdığın ellerinle bir fanus yapmalısin.)

Lerzîden be-çî̀î veya ber-kesî (üzerine titremek) tabiri bir şey veya kimse için özen ve sevgi göstermek anlamındadır. İkinci mısrada ise "elinle kendi etrafına bir fanus yap" ifadesi bu deyimin gerçek manasıyla ele alındığını göstermektedir.

$$
\text { به خون خويش آسان نيست دست از آرزو شستن / ز هر ناشسته رويى كى وضوى عشق مى آيد؟ (Sâib G.3200/9) }
$$

(Kendi kanınla arzudan el yıkamak [ümidi kesmek, vazgeçmek] kolay değildir. Her yıkanmamış yüz [= cahil] aşk abdesti nasıl alır?)

Dest şosten ez (-den el ylkamak) ümidi kesmekten kinaye olarak kullanılan bir deyimken nâ-şoste-rûy (yıkanmamış yüz, cahil) ve vuzû-yı 'sşk (aşk abdesti) gibi tabirlerle birlikte kullanarak deyimin lafzî manasını daha çok vurgulamıştır.

\section{Ey dil-i bâd-be-kef eyleme tazŷ̀'-i nefes}

Her kişi 'Îsi-i Meryem gibi meşhûr olmaz (Fehîm Kıt'a.1/1)

Bâd-be-kef (elinde hava[dan başka bir şey olmayan]) tabiri nasipsizlikten kinaye olmakla birlikte tazyı̂'i nefes (nefesini tüketmek) tabiri ve Îsâ ile birlikte birlikte düşünüldüğünde gerçek anlamlarının da göz ardı edilemeyeceği görülmektedir. Bilindiği gibi Îsâ (as)'ın bir mucizesi de ölüleri nefesiyle diriltmektir. Tazŷ̀'-i nefes tabirini de gerçek (lâzım) ve mecazi (melzûm) anlamlarıyla anlamak uygundur.

Bundan biraz farklı olarak îhâm-ı kinâyî (kinayesel îhâm) vardır. îhâm-ı istiârî-yi kinâye'den farkının anlaşılması için birkaç örnek vereceğiz. Aşağıdaki beyitlerde bazı karineler vasıtasıyla başa çıkmak, göz dikmek (dîde-dûz), el çekmek ve ölüp ölüp dirilmek deyimlerinin gerçek manalarına da işaret (îhâm) söz konusudur, ancak kinayeden murad olunan mecazî anlam bu beyitlerde esastır:

Çıkmaz benefşe sünbül ile başa n'eylesin

Durmuş çemende boynun eger nâtüvânlanır (Nâilî-i Kadîm G.44/2)

Başa çıkmak: Sünbülün saçla benzerliği dolayısıyla başta tasavvur olunması [lâzım] ve üstesinden gelmek [melzûm].

Sevgilinin kirpiklerinin şivesine hasretle göz dikmek ve yatağının iğne ile dolu olması:

Şîve-i müjgân-i yâre dîde-dûz-i hasretem

Câme-hâb-i râhatum leb-rîz-i sûzendür bu şeb (Sâmî G.15/2)

Şekil itibariyle ele benzeyen mercanın pençe olarak nitelenmesi ve denizden el çekmek: 
Görüp dür-dâne-i eşk-i dü çeşmüm pençe-i mercân

Kızarmış şermsâr-ı reşk olup deryâdan el çekmiş (Neşâtî G.62/3)

Çok istemek anlamında ölüp ölüp dirilmek ve sevgilinin dudağının âşı̆̆a can vermesi:

Ölür ölür dirilir ehl-i keyf bu şekere

Fe-keyfe olmaya rindâna la'l-i nâb lezîz (Şeyh Gâlib g.43/3)

Aşağıda mum ve alev terimleri dolayısıyla rûy-ı germ (sıcak yüz, sevgi ve şefkatten kinaye) tabirinin gerçek manasına îhâm vardır:

$$
\text { روى كرمى جو نبينيم بكس وا نشويم / نخل موميم بجز شعله نجيند بر ما (Kelîm G.5/11) }
$$

(Sıcak bir yüz görmediğimizde kimseye açlmayız. Mum ağacıyız, bizden kimse alevden başka meyve toplayamaz.)

\section{Paradoksal ifadeler}

Hint üslubu şiirindeki paradoksal ifadeleri terkîbî ve gayr-ı terkîbî olmak üzere iki kısma ayırabiliriz. Terkîbî paradoks iki zıt unsurun bir birleşik kelime veya tamlamada bir araya gelmesiyle oluşur. âb-1 huşk, âteş-i ter gibi. Terkîbî olmayan (gayr-ı terkîbî) paradoks ise bir mısra veya beyitte dile getirilen düşüncenin çelişki içermesiyle oluşur.

\subsection{Terkîbî}

Farklı terkîbî paradoks örneklerine rastlanmakla birlikte âteş-i ter ve âb-ı huşk terkiplerinin daha sıklıkla kullanıldığı görülmektedir. Ancak bu tabirler Sebk-i Hindî şairlerinden önce de kullanılmıştır. Âteş-i ter terkibinin genellikle şarap için kullanıldığını söyleyebiriz. Keza Sebk-i Hindî üslubundan çok daha önce şaraba âteş-i seyyâle (akan ateş) denildiği de malumdur.

Ateş - su münasebetine bir hadîs-i şerifte de rastlıyoruz. "Muhakkak ki denizin altında ateş, ateşin altında su vardır"3 mealindeki bu rivayete Fars şairi Menûçehrînnin (ö. 1040) şu beyitte telmihte bulunduğunu söyleyebiliriz:

$$
\text { اين جنين نارى كجاباتشد، بهزير نار آب / وان جنان آبى كجا باشد، بهزير آب نار (Menuçehri K.16/12) }
$$

(Böyle bir ateş nerede olur, ateşin altında su! Ve öyle bir su nerede olur, suyun altında ateş!)

Hâkânî (ö. 1199) ve Attar (ö. 1221) gibi kudemadan şairlerde de rastladığımız âteş-i ter ve âb-ı huşk tabirleri Nizâmî (ö. 1214) ve Câmî’nin (ö. 1492) mısralarında çok açık bir şekilde şarap ve kadeh anlamında kullanılmaktadır:

$$
\text { بيا كه خشكى و نرى طفيل هنتى ماست / در آب خشك قدح ريز آتش تر مى (Câmî G.990/2) }
$$

(Gel, zira kuruluk ve ıslaklık bizim varlığımızın yoldaşıdır. Kadehin kuru suyuna ıslak ateşi dök.)

$$
\text { باده در جام آبكينه كُر / راست جون آب خشك و آتش تر ) Nizâmî, Heft Peyker.25/45) }
$$

(Şarap billur kadehte [iken] tam anlamıyla kuru su ile ıslak ateş [gibidir].)

Hint üslubu şairleri de bu terkibi aynı manada sıklıkla kullanmışlardır:

3 إن تحت البحر نارأ وتحت النار بحرأ : Hadîs-i şerîf, Ebu Davud'un rivayeti. 
Hâkden ref'e bizi yâr-i hevâyî-meşreb

Âb-1 huşk elde gerek âteş-i ter âmâde (Hâzık G.182/2)

Bu âb-1 huşk biraz da turursa meclisde

Cihânı âteş-i ter sû-be-sû yakar yıkar (Nevres-i Kadîm, G.40/3)

Neşâtî ise su - ateş birlikteliğini nâr-ı âb-pûş (su giyinen veya suya bürünen ateş) terkibiyle dile getirmiş, böylece bu eski anlam ilişkisini yeni bir formda sunmuştur:

Pertev-nümâ-yı şevk it ol nâr-ı âb-pûşı

Bezm-i safâyı sâki pür-âb u tâb göster (Neşâtî g.18/6)

Bunun yanı sıra hem kudemanın hem de Sebk-i Hindî şairlerinin sevgilinin yüzü için de âteş-i ter tabirini kullandı̆̆ görülmektedir:

Ne yüz bu ki âteş-i ter olmış

Ne leb bu ki âb-ı kevser olmış (Ahmedî G.305/1)

Ruhuna âteş-i ter rûyuna güldür demeden

Sûziş-i aşkı bu vech ile edâdır matlab (Şeyh Gâlib G.22/4)

Şeyh Gâlib aşağıdaki beyitte gark ve mevc gibi suyu çağrıştıran kelimeleri zikr ederek istiare yoluyla sevgilinin yanağını bir ateş denizine benzetmiştir. Şair çoğu zaman yaptığı gibi sevgiliye ait birtakım unsurları zikrettikten sonra (hâl = ben; ruh = yanak) onun hasreti ve hayaliyle kendi bedenine ait unsurlar (şu'le-i eşk = gözyaşı ateşi; sevâd-ı çeşm=gözbebeği) arasında paralellik kurmuştur:

Hasret-i hâl-i ruhunla gark-1 mevc-i âteşiz

Şu'le-i eşkin sevâd-ı çeşmimiz Hindûsudur (Şeyh Gâlib G.51/5)

Ateş ve su gibi iki zıt unsurun bir araya gelmesiyle ilk bakışta zahirî tenakuz oluşsa da kastedilen mana itibariyle düşünüldüğünde ortada bir çelişki olmadığı görülmektedir. Zira ateş-i ter ile kastedilen kadeh ve/veya sevgilinin yüzü, âb-ı huşk ile kastedilen ise kadehtir. Burada akla ve mantığa aykırı bir durum olmadığı açıktır.

Nâbî, Nâilî ve Esrar Dede'nin dile getirdikleri reng-i 'amâ (körlük rengi), reng-i bî-rengî (renksizlik rengi), zâhid-i meyhâne (meyhanenin zahidi), rind-i hankâh (dergâhın rindi), sâye-i bî-sâye (gölgesizin gölgesi), âteş-i Kevser-nijâd (Kevser suyu tabiatlı ateş), güftâr-ı hâmûşî (suskunluğun sözü) tabirlerini paradoksal terkipler arasında sayabiliriz:

Behresi dest-i musavvirden olur reng-i 'amâ

Nâbiyâ her kim ki istimdâd ide tasvîrden (Nâbî G.644/9)

Reng-i bî-rengîden âgeh dillerin ey Nâ'ilî

Zâhid-i meyhâne rind-i hânkâhdır her biri (Nâilî G.362/5)

Sâye-i bî-sâye-i zât-ı hudâvend-i hakîm

Mazhar-ı hâş-ı vücûd-ı Hâlık u cân-ı hikem (Esrâr Dede K.1/37)

La'l-i lebi ki âteş-i Kevser-nijâddır

Hızr-ı hayât aşkı ile mey-fürûş olur (Gâlib G.87/4)

La'l-i aşka kuvvet-i güftâr-ı hâmûşî nedir 
Hayret-i vaslınla her mûyum zebân olsun da gör (Gâlib G.71/2)

Burada da bî-rengî (renksizlik, vahdet, tevhîd) ve 'amâ (bulut, körlük, ahadiyyet mertebesi) tabirlerinin tasavvufî birer ıstılah olduklarını ve böylelikle tasavvufa mahsus birtakım düşüncelerin paradoksal izlenimi oluşturacak bir formda dile getirildiğini söyleyebiliriz.

\subsection{Gayr-1 terkîbî}

Mısra veya beyitte dile getirilen düşüncenin tenakuz içerebildiği terkîbî olmayan paradoksal ifadelere de rastlanmaktadır.

Bidil'in lafzî bir çeviriyle Türkçeye aktaracak olursak "kendine âşinâ ol yani kendinden bîgâne ol” dediği aşağıdaki beyitte bir paradokstan söz edilebilir:

$$
\text { بيوفايى صورت رنح بهار زندخىست / آشناى خويش شو يعنى ز خود بيحانه باش (Bidil, G.1764) }
$$

(Vefasızlık, hayat baharının renginin suretidir. Kendine âşinâ ol, yani kendinden bîgâne ol.)

$\mathrm{Bu}$ beyitteki tenakuz bîgâne ve âşinâ kelimelerinin aynı mısra veya beyitte geçmesinden kaynaklanmıyor. Sadece zıt anlamlı kelimelerin bir arada kullanılması tenakuzun oluşması için yeterli değildir. Beyitte şairin dile getirdiği düşünce bir bütün olarak çelişki içermektedir. Elbette zi hod bîgâne şoden tabirinin tasavvufî bir ıstılah olduğunu ve "kendinden kurtulmak, kendinden geçmek" anlamlarında kullanıldığını dikkate aldığımızda bu çelişki ortadan kalkabilir. Zira tasavvuf terminolojisinde bu tabir vecd hâlini ifade etmek için kullanılır ve vecd hâli ise hakikate ulaşmanın, dolayısıyla kendini tanımanın yoludur. Fakat bu bilgi beytin zahirî manasındaki tenakuzu ortadan kaldırmaz ve şair bunu yaparken şiir okurunu şaşırtacağını, düşünceye sevk edeceğini hesap etmiş olmalıdır.

Şevket aşağıdaki beyitte sesi bir aleve benzetir, suskunluğu ise o alevi muhafaza eden bir fanus olarak tahayyül eder. Ardından nutkun yani konuşmanın dilin rüzgarıyla öleceğini yani söneceğini ifade eder. Şu hâlde şairin konuşabilmesi için dilini kımıldatmaması ve suskunluk fanusuyla onu rüzgardan muhafaza etmesi gerekmektedir:

$$
\text { خموشى شعلة آواز را فانوس مى باثند / جر اغ نطق ما از باد دامان زبان ميرد (Şevket G.365/2) }
$$

(Suskunluk, ses ateşi için bir fanustur. Bizim konuşma mumumuz dilin eteğinin rüzgarıyla söner.)

Sâib ise hiçbir iz ve işaretin olmadığı bu nişansızlık dünyasında nişansızlığın kılavuz olduğunu söylemektedir:

$$
\text { بى نشانى درجهان بى نشانى رهبرست / در بيابان طلب سنى نشانى كو مباش (Saib G.4887/17) }
$$

(Nişansızlık dünyasında nişansızlık rehberdir. Talep çölündeki nişan taşına de ki: “Olmazsan olma!")

$$
\text { به ناكامى سر آور تا به كام دل رسى صائب / نر اند هر كه كام از خود، نكردد كامر ان اينجا (Saib G.316/7) }
$$

(Kâmszilıkla iyi geçin ki gönlünün kâmına ulaşasın. Kendinden kâmı sürmeyen [uzaklaştırmayan], burada kâm süremez.)

Bazı beyitlerde ilk bakışta çelişki var hissi uyandırsa da hakikatte çelişki olmayabilir. Ancak bu tarz beyitlerde de şairin okuru şaşırtmak istediği ve özellikle çelişkili bir şey söylüyor izlenimi uyandırmaya çalıştı̆̆ını varsayabiliriz. "Hayal deniziyiz ve burada bir ıslaklık yok" diyen Bîdil’in bu cümlesi zâhiren ve bâtınen çelişki içermemektedir: 


\section{درياى خياليم و نمى نيست در اينجا / جز و هم وجود و عدمى نيست در اينجا (Bidil G.21/1)}

(Hayal deniyiz ve burada bir ıslaklık yok. Burada varlık ve yokluk vehminden başka bir şey yok.)

Nâilî-i Kadîm ve Şeyh Gâlib ise adeta bu tenakuz içeren yaklaşımın sırrını ifşa ediyorlar ve bu hâliyle artık tenakuzdan da söz edemiyoruz:

Cihân-1 vâjgûn-na'l-i mahabbet özge âlemdir

Gedâdır şâhlar cümle gedâlar pâdişâhdır hep (Nâilî-i Kadîm g.18/3)

Deyr-i aşkın büt-perestânı heme Hak-bîndir

Berhemenler sûret-i dîvâra etmez iltifât (Şeyh Gâlib g.25/3)

Bu beyitlerde bir yerden veya bir hâlden bahsedildiği ve burada durumun alıştığımız dünyadan farklı olduğu söyleniyor. Nâilî-i Kadîm muhabbet dünyasının başka bir âlem olduğunu aşk mabedinin put perestlerinin Allah'ı gören, bilen kimseler olduğunu söylüyor.

Neşâtî, adsız sansız olduğu hâlde âleme nam saldığından bahsederken okuru düşünceye sevk edecek bir iddiada bulunuyor:

Olsak no'la bî-nâm ü nişân şöhre-i 'âlem

Biz dil gibi bir turfa mu'ammâda nihânuz (Neşâtî G.50/3)

Şairin ikinci mısrada muamma tabirini zikretmesinden cesaret alarak şunu söyleyebiliriz ki bu paradoksal ifadeler her ne kadar çelişkili, akla ve mantığa aykırı gibi görünse de aslında kendi içinde bir mantığa sahiptir. Şair bir bilmece (muamma) gibi kurguladığı bu mısralara onu çözmeye yarayacak ipuçlarını da (karîne) yerleştirmiştir. Fakat bu karîne ne kadar gizli (nihân) olursa Sebk-i Hindî şairlerinin arzu ettiği "zor ulaşılan mana" hedefi bakımından o kadar başarılı olacaktır (İlhâmî 1387: 3745).

\section{Hiss-âmizî}

Batı dillerindeki sinestezi tabirinden esinlenerek hissâmizî (his karmaşası) olarak adlandırılan bu üslup özelliği Türkçeye çoklu duyulama (Mum 2005: 134-135), duyumlar arası geçiş (Babacan 2010: 190) gibi kavramlarla aktarılmıştır.

Hiss-âmizî bir duyuya ait bir özelliğin başka bir duyuyla ilgili unsura atfedilmesidir. Aslında bu tür ifadeler günlük dilde de mevcutttur. Örneğin tatlı söz (tatma - işitme), ekşi suratlı (tatma - görme) gibi ifadelere günlük hayatta rastlarız. Fakat bunlar duymaya alıştığımız söz öbekleri olduğu için bizi yadırgatmaz. Hint üslubu şairleri ise gündelik dilde ve şiirde az sayıda bulunan bu ifade biçimini yaygınlaştırmışlar, farklı duyulara ait unsurlar arasında yeni ve alışılmamış bağdaştırmalar yapmışlardır. Dolayısıyla bu ifade biçimi Hint üslubu şairlerinin ma’nâ-yı gar̂̂b (yabancı, alışılmamış mânâ) tabiriyle dile getirdikleri şiir anlayışına uygun garip anlamların ortaya çıkmasına katkı sağlamıştır.

Hiss-âmizî her ne kadar Türkçede duyular arası geçiş veya çoklu duyulama olarak adlandırılsa da duyuyla algılanmayan zihnî kavramları duyulara ait unsurlarla ifade etmeyi de (bûy-ı tegâfül, reng-i gurûr gibi) kapsamaktadır. Bu sebeple söz konusu hususiyeti "his karmaşası" kavramıyla ifade etmeyi tercih ediyoruz. Buna göre his karmaşasını yapı bakımından hissî - hissî ve zihnî - hissî olmak üzere iki kısma ayırmak mümkündür. 


\subsection{Hissî - hissî}

İki duyuya ait husisiyetler veya unsurlar arasında geçişin olduğu duyu karmaşaları dokuz çeşittir. Yaptığımız taramalarda koklama - dokunma ve koklama - tatma duyuları arasında geçiş örneğine çok az rastlanmıştır.

\subsubsection{Görme - İşitme}

His karmaşasının en yaygın biçimi görme ve işitme hislerine ait unsurlar arasında görüler. Bunlar arasında "tatlı söz" (suhan-ı şî̂n) gibi gündelik dilde rastlanan örneklerin yanı sıra şairlerin kendilerine has bağdaştırmaları da vardır. Şairlerin yaratıcılığını yansıtan bazı orijinal örnekler Sebk-i Hindî şiirinin geleneksel üsluptan farkını teşhis etmek bakımından önemlidir.

Bîdil aşă̆ıdaki bir beyitte ayak izini işittiğini söylerken, diğerinde de ayak izinin feryadından bahsetmektedir:

كه مئرد بيام دوستان رفته زين محفل / مكر از نقش بايى بشنويم آو از با اينجا (Bîdil G.11/7)

(Bu meclisten gitmiş dostların haberini kim getirir. Burada ancak bir ayak izinden ayak feryadını işitiriz.)

$$
\text { ياد ايامى كه در صحر اى بِرشور جنون / همجو موج سيل نقش بِاى من فرياد داشت (Bîdil G.811/9) }
$$

(Divaneliğin coşku dolu çölünde ayak izimin sel dalgası gibi feryat ettiği o günleri andım.)

Bazı hadis-i şeriflerde göze çekilen sürmenin görme gücünü artırdığı belirtilir. Eski bir halk inanışına göre ise sürme ses kısıklığına yol açar. Şeyh Gâlib’in hamûşân, nazar, sürme ve âvâz kelimelerini bir arada kullanarak sürmeye dair bu bilgilerin mezc olduğu aşağıdaki beytinde sürme-i âvâz ve hamûşân-1 nazar tabirlerinde de görme - işitme duyuları arasında bir karmaşa vardır:

Nây-ı âteş-dem hamûşân-ı nazar dem-sâzıdır

Sürme-i âvâz dûd-ı şu'le-i âvâzıdır (Şeyh Gâlib G.55/1)

(Ateş nefesli ney hamûşân-ı nazar'ın (bakış suskunlarının) sırdaşıdır ve ney sesinin ateşinden çıkan duman ses sürmesidir.)

Görme ve işitme duyuları arasında karmaşanın görüldüğü diğer bazı örnekler şunlarır:

Her bir nazarun olsa Kelîm-i “Erinî"-gû

Ey dîde-i ter şâhid-i câvîd görinmez (Şehrî g.54/3)

(Ey yaşlı göz, her bir bakışın “erinî” (bana kendini göster) diyen Kelîm (= Hz. Mûsâ) olsa da ebedî güzeli göremezsin.)

Söz bir itdükde iki çeşmân-ı gûyâ-yı kebûd

Birbiriyle san iki tûtî-i ahdar söyleşür (Muvakkitzâde Pertev G.102/2)

(Konuşan iki yeşil göz söz birliği ettiğinde sanki iki yeşil papağan birbiryle konuşur gibidir.)

Şâhid-i gamzesini serhôş u raks-âver ider

Nagme-i 'işveye çeşmi ki ser-âgâz eyler (Fehîm G.58/3)

(Gözü işve nağmesine başladığında güzel [bir sevgiliyi andıran] gamzesini sarhoş eder ve dans ettirir.)

Ne kadar güft ü şenîd eyledügin ehli bilür

Dehen-i beste-i hüsn ü leb-i hâmûş-ı nigeh (Nâbî G.806/2)

Ser-i sükkân-ı sümuvvâta olurdı nấil 
Nâbiyâ olsa eger çeşmi kadar gûş-1 nigeh (Nâbî G.806/7)

(Ey Nâbî, eğer [o güzelin] gözü kadar bakış kulağı da olsa yüceliklerin ahalisine nail olurdu.)

Hezâr nagme-i rengîn işitdüm ey Nâbî

Sadâ-yı kulkul-ı meydür kalan kulagumda (Nâbî G.750/6)

Reng-i suhan lebinde güher-pâre-rîz-i şevk

Bir dil-ber-i şikeste-zebân söylerüm sana (Sâmî g.2/6)

(Sana peltek bir güzelden bahsederim ki söz rengi onun dudağında şevk mücevheri parçaları döker.)

\subsubsection{Görme - Koklama}

Sâmî sevgilinin gülü andıran güzel yüzünü seyrederken adeta bu gülün kokusunu uzaktan hissetmiş ve meşâm-ı nigâh yani bakışın burnu tabiriyle durumu ifade etmiştir:

Gül-i 'izârı ki ser-şişe-zîb-i bâsıradur

Şemîm-bahş-i meşâm-i nigâhum olmışdur (Sâmî G.36/2)

(Görme yetisi şişesinin [= gözün] süsü olan yanağının gülü, bakışımın burnuna güzel kokular bağışladı.)

Meşâm-ı nigâh tabiri sevgilinin şair için ulaşılmaz oluşunun da bir ifadesidir. Zira bu gülü burnuyla koklayabilimesi için yeterince yakın olması gerekir. Oysa şair onu ancak uzaktan seyredebilmekte ve gözüyle koklayabilmektedir.

\subsubsection{Görme - Dokunma}

Nigâh-ı germ tabiri gerek klasik üslup şairleri ve gerekse gündelik dilde kullanılması sebebiyle alışılmış bir bağdaştırma olsa da his karmaşasına örnek olarak olarak gösterilebilir:

Ne hırmen-i dil ü ne hânümân-ı sabr kalır

Nigâh-ı germi gibi berk-ı cân-güdâz olıcak (Nâilî G.193/2)

(Sıcak bakışı gibi can eriten şimşek olduğunda ne gönül harmanı ne de sabır evi kalır.)

\subsubsection{Görme - Tatma}

Aşağıdaki beyitlerde geçen his karmaşası örneklerinden reng-i halâvet (tatlllık rengi) tabiri aynı zamanda alışılmamış bir bağdaştırmayken türş-rû (ekşi yüz) ise gündelik dilde rastlanan bir tabirdir:

$$
\text { مخو اه رنح حلاوت زكفتكو بيدل / نيى كه ناله كند قابل شكر نبود (Bîdil G.1498/9) }
$$

(Ey Bîdil, sohbette tatlılık rengi arama. İnleyen bir neyde şeker tadı bulunmaz.)

Türş-rû gösterme cânâ zerdî-i rûyum görüp

'İllet-i sevdâ-yi 'âşık âb-i lîmûn istemez (Sâmî G.48/2)

Hint üslubu şairlerinde rastlanan lezzet-i dîdâr (Mezâkî G.103/3; Sâmî G.62/6; Fehîm G.47/8; Ş. Gâlib G.149/2; Şehrî K.3/37) terkibinde de görme ve tatma duyularına ait unsurlar bir araya gelmiştir.

\subsection{5. İşitme - Koklama}

Aşağıdaki beyitte geçen şemîm-i sühen (söz kokusu) işitme ve koklama duyusuna ait unsurlardan mürekkeptir: 
A'dâya midâd-ı kalemim reşha-i semmdir

Ahbâba şemîm-i sühenim nükhet-i cândır (Nefî K.9/43)

(Düşmanıma kalemimin mürekkebi zehir damlasıdır. Dostlara sözümün kokusu can bağışlayan güzel bir kokudur.)

\subsection{6. İșitme - Tatma}

Tatlı söz (sühan-ı şîrîn) klasik üslup şairlerinde, Türkçe ve Farsça gündelik dilde rastlanan bir his karmaşası örneğidir:

Dili söyletmege besdür sühan-1 şîrînün

Tûtiyân-ı kafes-i 'aşk şeker bilmezler (Nâbî G.222/6)

(Tatlı sözün gönlü konuşturmak için yeterlidir. Aşk kafesinin papağanları şeker bilmezler.)

Yüri zenbûrdan ey nâle meşk it fenn-i te'sîrün

K'içer her nîş nîş nâlesinden çeşme çeşme nûş (Şehrî G.64/2)

(Ey inleyiş, git ve arıdan tesirin usulünü öğren. Zira o zehir gibi inlemesinden çeşme çeşme bal içer.)

Tatma duyusuna ait lezzet kelimesiyle işitme duyuyla ilgili olan güftâr (söz), nâliş (inleme) ve nutk (konuşma) kelimeleri arasında yapılan terkipler de bu kapsamda sayılabilir. Lezzet-i güftâr terkibi klasik üslup şairleri tarafından da kullanılırken lezzet-i nâliş (Nâbî G.459/5) ve lezzet-i nutk (Haşmet K.7/53; Nâbî K.17/29) terkipleri Hint üslubu şairleri tarafından kullanılmıştır.

\subsection{7. İşitme - Dokunma}

Farklı duyularla ilgili olan suhan (işitme) ve serd (dokunma) kelimelerinden oluşan suhan-i serd, nevâ (işitme) ve germ (dokunma) kelimelerinden oluşan nevâ-yı germ tabirleri bu his karmaşasına örnek olarak gösterilebilir.

Gehver-i gûş-ı kabûl eyleyen ednâ suhanun

Şimdi eyler suhan-1 serd ile kasd-ı ilzâm (Nâbî K.12/31)

(En değersiz sözünü bile kabul kulağına inci [küpe] yapan, şimdi soğuk söz ile susturmaya çalışır.)

Bahar oldı yine âheng-i nevrûz eylesün bülbül

Nevâ-yı germ ile 'uşşâkı pür-sûz eylesün bülbül (Fehîm-i Kadîm G.192/1)

(Bahar geldi, bülbül yine nevrûz şarkıları söylesin. Sıcak sesiyle âşıkların gönlünü yaksın.)

\subsubsection{Koklama - Dokunma}

Nedîm'in beytinde geçen gül kokusuna (koklama) yara açmak (dokunma) tabiri hem alışılmamış bir bağdaştırma olmasına rağmen aynı zamanda garabetten uzak, gayet şairane bir ince hayal örneğidir:

Zahm urma bûy-ı gül dahi olursa 'âşııın

Yelmân-ı tîğ-i nâza meded zahmet olmasın (Nedîm G.91/5)

(Gül kokusu dahi sana âşık olursa onu yaralama. Aman, naz kılıcının ucuna zahmet olmasın.) 


\subsubsection{Koklama - Tatma}

Koklama ve tatma duyuları arasında geçişlerle ilgili Türkçe divanların taradığımız kısımlarında bir örneğe rastlamadık. Fars şiirinde rastladığımız örnekler ise teşne (susamak) kelimesinin mecazî anlamda (bir şeye hasret olmak) kullanılmasından oluşmaktadır ve bu gündelik dilde de görülen bir kullanım şekli olması sebebiyle alışılmamış bağdaştırma kapsamında değildir. Fakat Tâlib’in beytinde geçen "bahar kokusunun kana susaması" imgesi bir bütün olarak alışılmamış bir bağdaştırma örneği olarak düşünülebilir.

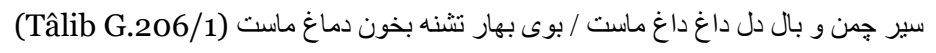

(Kanat [çırpma arzusu] ve bahçe seyri [ile] bizim gönlümüz dağ dağ olmuştur. Bahar kokusu bizim şuurumuzun ${ }^{4}$ kanına susamıştır.)

ز بس كه تشنـة بوى وفاى نايابم / به دستم ار كل كاغذ دهند مى بويم (Sâiib G.5775/3)

(Bulunamayan vefa kokusuna öyle teşneyim ki elime eğer kağıt gül5 verseler koklarım.)

\subsection{Zihnî - hissî}

Hiss-âmizî (his karmaşası) yukarıdaki örneklerde görüldüğü üzere duyular arasında olabiliceği gibi duyulara ait bir özelliğin zihnî bir kavrama izafe edilmesi yoluyla da olabilir.

\subsubsection{Koklama}

Genellikle bûy kelimesi ile mücerred kavramların terkibinden oluşan birçok örneğe rastlanmaktadır. Benzer şekilde renk kelimesinin de mücerred kavramlarla kullanıldığı birçok terkip mecvuttur. Bûy kelimesinin mecazen iz, eser; renk kelimesinin mahiyet, vasıf anlamlarını dikkate aldığımızda bu terkiplerde his karmaşası olmadığı da söylenebilir. Diğer yandan şairler bu kelimeleri, hakikî veya ilk anlamlarını da çağrıştıracak şekilde şiirde kullanmaya özen göstermişlerdir. Örneğin aşă̆ıdaki beyitte yer alan bûy-ı sebât terkibinde bûy kelimesinin mecazî anlamı (eser, iz) ilk bakışta daha baskındır. Fakat ikinci mısradaki gülşen kelimesi sebebiyle kelimenin hakîkî anlamı da (koku) aynı derecede geçerlidir.

Hîç birinde bulamaz reng-i bekâ bûy-1 sebât

İtse gül-geşt-i sabâ 'âlemi gülşen gülşen (Nâbî G.643/2)

(Tan yeli dünyayı gülşen gülşen dolaşsa da hiç birinde bekâ rengi ve sebat kokusu bulamaz.)

Gülşen-i hüsne ne nîreng-i tılısm etmişler

Bûy-1 telvîn gelir gonca-i temkîninden (Şeyh Gâlib G.235/5)

(Güzelliğin gül bahçesine nasıl bir tılsım yapmışlar ki temkîn goncasından [bile] telvîn kokusu gelir.6)

Neş'e-i nâz degil ser-hoşî hâb degil

Nergis-i şûhdaki bûy-ı tegâfüldür bu (Şeyh Gâlib G.271/4)

(Naz neşesi değil, sarhoşluk uykusu değil. Bu, nergise benzeyen cilveli gözdeki bilmezden gelme kokusudur.)

\footnotetext{
4 (دماغٔ) dimâğ (akıl, şuur) / demâğg (burun, kibir): koku ve demâğ kelimesi arasında îhâm-ı tenâsüb vardır. Yani şair kastetmediği anlamı sezdirmektedir.

5 gol-i kâğez (kâğıt gülü, kâğıt gül): Kâğıt gülü (begonvil = bougainvillea) kokusu olmayan bir gül çeşididir. Dolayısıyla hem kâğıt gülü (begonvil) veya hem de "kâ̆ğttan yapılmış bir gül” anlamları beyit açısından uygundur.

Telvîn: Renklendirme, boyama. Tasavvufta hâlden hâle girme. Temkîn: Tasavvufta hâl ve makamları geçip karar bulma,
} kemâle erme. 


\subsubsection{Görme}

Aşağıdaki beyitlerde "gözde intizarın su olup damlaması" ibaresi ve reng-i neşât (neşe rengi), reng-i günâh (günah rengi) terkiplerinde zihnî kavramlara görme duyusuyla ilgili özellikler atfedilmiştir:

$$
\text { از بس به راهو عده خوبان نشسته ايم / در ديده آب كثت و جكيد انتظار ما (Şevket G.119/11) }
$$

(Güzellerin vaat ettikleri yolda öyle çok oturduk ki beklememiz gözümüzde su olup damladı.)

Geldi Gâlib tab'a bir reng-i neşât

Gül gibi açıldım ammâ gülmedim (Gâlib G.227/9)

Reng-i günâhı eyleyen ebrû-yı magfiret

İtmiş hatâyı şâne-i gîsû-yı magfiret (Nâbî G.23/1)

(Günah rengini mağfiret kaşı eyleyen [Allah] hatayı da mağfiretin saçına tarak yapmış.)

Nâbî’de çokça rastlanan bu tür terkiplerin bazıları şunlardır:

Reng-i rizâ (G.143/4), reng-i 'adem (G.398/7), reng-i hestî (G.403/4), reng-i sitem (G.684/1), reng-i hayât (G.697/1), reng-i telâş (G.70o/3), reng-i istiklâl (G.748/3), reng-i ta'alluk (G.710/7).

\subsubsection{Dokunma}

Hüsn-i gelû-sûz (boğazı yakan güzellik) ve gelû-sûz-ı hıred hüsn (aklın boğazını yakan güzellik) terkiplerinde mücerred bir kavram olan güzelliğe dokunmaya duyusuna ait bir hususiyet olan yakıcılık atfedilmiştir:

Dü bâlâdur o çâr ebrû ile hüsn-i gelû-sûzun

Bakılsa sâde-rûyâna nigeh nâ-çârdur sensüz (Sâmî G.50/4)

Mu'ciz-i hüsnün gelû-sûz-ı hıred itmiş kader

Çeşm-i gül-çîninde yokdur cümle varı mû kadar (Sâkıb Mustafa musammat 1/X/1)

\subsection{4. İşitme}

Can kulağı tabirinde görüldüğü gibi zihnî bir kavrama işitme duyusuyla ilgili bir özelliğin atfedilmesi gündelik dilde de mevcuttur. Hint üslubu şairleri belki de bu ve benzeri formları esas alarak yeni bağdaştırmalar oluşturmuşlardır.

Gûş-ı ârzû (arzu kulağı) ve nevâ-yı tevfik (tevfîk nağmesi):

Sadef-veş dürr-i şâd-âb-ı kelâmın etmege ısgâ

Küşâd olmakda gûş-ı arzûlar hep seninçündür (Şeyh Gâlib G.97/4)

(Kelamın suya kanmış incisini sedef gibi dinlemek için açılmakta olan arzu kulakları hep senin içindir.)

Tab'ı bir bülbül-i hoş-lehçe-i 'irfândır kim

Nâlesi gülbün-i ma'nâda nevâ-yı tevfîk (Haşmet K.14/25)

([Onun] mizacı; ma’nânın gül fidanında tevfik nağmesini terennüm eden hoş lehçeli bir irfan bülbülüdür.) 


\subsubsection{Tatma}

Sebk-i Hindî şairleri tatma duyusuyla ilgili olan lezzet kelimesini bazı mücerred kavramlarla bir araya getirerek birçok tamlamalar yapmışlardır.

Nâbî’nin aşağıdaki beytinde, lügat manasıyla alınacak olursa, zevk kelimesi de tatma duyusuyla ilgili bir kelimedir:

Lezzet-i nâza gerçi söz yokdur

Lîk zevk-i niyâza 'aşk olsun (Nâbî G.628/2)

'Iyâr-1 lezzet-i eş’âra noksân gelmez ey Nâbî

Zebân-ı hâmeye oldukça şekker-hâne dirlerse (Nâbî G.672/5)

Lezzet-i nazm (Sâmî G.97/4) ve lezzet-i ma'nâ (Nâbî G.805/7; Neşâtî G.94/5) terkipleri de bu bağlamda sayılabilir.

\section{Yeni terkipler}

Alışılmamış bağdaştırmalar farklı şekillerde olabilir. paradoksal ifadeler. mantıken birbiriyle ilgisi kolaylıkla kurulamayan unsurlar arasında. soyut ve somut unsurların bir araya getirilmesi.

\subsection{Soyut - Somut (Somutlaştırma)}

Soyut bir kavram ile somut bir nesnenin terkibinden oluşan bu tür yapılar genellikle izâfet-i teşbîhiyyedir. Yani terkibi oluşturan soyut unsur (müşebbeh), somut unsura (müşebbhün bih) benzetilmektedir. Oluşturulan bu benzetmeye beyit içinde ilişkili başka benzetmeler eşlik eder. Böylece beyit, soyut bir hadisenin tüm bağlı unsurlarıyla somutlaştırıldığı ve zihinde resmedildiği bir tabloyu andirır.

Aşağıdaki beyitte nâz ve niyâz kavramları birbiriyle uyumlu bir şekilde nakd (geçer akçe) ve kâle (kumaş) somutlaştırılmış ve bir çarşı tasviri içinde sunulmuştur:

O çârsûda ki nakd-ı niyâza bakmazlar

Metâ'-1 kâle-furûşân-1 nâza bakmazlar (Nâilî-i Kadîm G.57/1)

(Niyaz nakdine değer verilmeyen bir çarşıda naz kumaşı satanların malına değer verilmez.)

Cân atar bî-çâre dil gâhî niyâm-ı nâzdan

Kasd-ı zahm-ı cân ile ol hançer-i ebrû çıkar (Neşâtî G.22/2)

(O kaş hançeri canı yaralama kastıyla naz kınından çıktığı zaman zavallı gönül can atar.)

Bu somutlaştırmalar her zaman için soyut bir kavramın, hadisenin veya düşüncenin daha iyi anlaşılması kaygısının eseri değildir. Şairler için bu yöntem orijinal ve yeni manalar üretmenin ve yaratıcılıklarını sergilemenin de bir aracıdır. Örneğin Nâbî̀nin aşağıdaki beyitte söylemek istediği şey “ölümden başka her derdin çaresi var" düşüncesidir. Fakat bu yaygın ve yalın düşünceyi ifade ediş şekli onun anlaşılmasını kolaytırmamış hatta bir ölçüde zorlaştırmıştır:

Pençe-i saht-ı gelû-gîr-i fenâdan gayrı

Yokdur ol zahm ki nâ-yâfte-i merhemdür (Nâbî G.118/5) 
(Faniliğin boğazı yakalayan sert pençesinden başka, merhemi bulunmayan bir yara yoktur.)

Türk ve Fars edebiyatında başka hiçbir şairde rastlamadığımız pençe-i saht-ı gelû-gîr-i fenâ terkibi tam olarak "ölüm" kavramına tekabül etmektedir. Nâbî̀de örneğine çokça rastlanılan bu tür somutlaş̧ırmalardan bazıları şunlarıdır: bâzâr-ı rüstehîz (kıyamet pazarı), dükkân-ı enbiyâ (peygamberler dükkânı), lihâf-ı hacâlet (utanma yorganı), nevâle-i ma'nâ (mana gıdası).

\subsection{Somut - Somut}

Somut nesneler arasında yapılan terkipler yapı bakımından dört kısımda incelenebilir: 1. İzâfet-i lâmiyye (Aitlik bildiren belirtili isim tamlamaları) 2. İzâfet-i beyâniyye (Bir şeyin türünü veya neden yapıldığını gösteren belirtisiz veya takısız isim tamlamaları) 3. İzâfet-i teşbîhiyye (Benzetme amacı güden tamlamalar) 4. İzâfet-i vasfiyye (sıfat tamlaması).

Farsça terkip yapısında izâfet-i vasfiyye dışındaki tamlamaların hangi izâfet grubuna ait olduğu ancak anlamdan çıkarılablir. Örneğin aşağıdaki beyitlerde geçen reg-i sâz (sazın damarı) terkibi aidiyet (izâfeti lâmiyye) bildirirken gül-i hodrûy-ı âfitâb (güneşin yaban gülü, yaban gülüne benzyen güneş) terkibinde teşbih (izâfet-i teşbîhiyye) vardır.

Neşâtî̀nin aşağıdaki beytinde sazın damarı tabiriyle kastedilen sazın telleridir, dolayısıyla bir istiare ve kişilertirme yapılmıştır:

İtmiş temâm zîr ü bem-i nâleden zuhûr

Hûnîn terâneler ki reg-i sâza sıgmamış (Neşâtî G.59/2)

(Kanlı teraneler sazın damarına sığmamış ve inlemenin tiz ve pes seslerinden zuhur etmiştir.)

Aşağıdaki beyitte gül-i hôd-rûy-ı âfitâb (güneşin kendi biten gülü, güneşin yaban gülü) terkibinde bir aidiyet değil benzetme söz konusudur:

Feyz-âşinâ-yı dâg-ı dil olmak muhâldir

Reng-i şikeste-i gül-i hôd-rûy-ı âfitâb (Nâilî G.11/2)

(Yaban gülüne benzeyen güneşin solgun rengi gönül yarasının feyzine âşinâ olamaz.)

Gûş-ı zebân (dilin kulağı) tabiri ise aidiyet bildiren bir yapıdadır, ancak Neşâtî'nin beytinde geçen reg-i sâz (sazın damarı) terkibine göre daha kapalı ve aralarındaki münasebet daha muğlaktır.

Ki nutkı gûş-ı zebânına irmemiş dahı

Kelâm-1 şi'rini bir ferde itmemiş iş'âr (Nevres-i Kadîm K.25/14)

(Şiirinin sözünü bir kişiye bile bildirmemiş hatta sözü dilinin kulağına dahi varmamış.)

Sözü duyulur hâle getirmesi gereken dil (zebân) kişileştirilmiş ve onun dahi duymadığı söylenerek mübalağa yapılmıştır.

Aşağıdaki beyitte âşı̆̆ın canı bir harmana sevgilinin kaşı ise hançer yağdıran bir buluta (ebr-i hançerrîz = izâfet-i mevsûfiyye) benzetilmiştir:

Yâd-ı müjgânunla âh eylerse diller rüzgâr

Hırmen-i cân üzre anı ebr-i hançer-rîz ider (Fehîm-i Kadîm G.53/4) 


\section{Tetâbu'-ı izâfât ve Farsça ifade kalıpları}

Tetâbu'-ı izâfât (zincirleme tamlama) Hint üslubundan önce de vardır. Fakat Hint üslubu şairleri bu tür tamlamaları daha çok kullanmışlardır. Bu tarz tamlamalar Fars Sebk-i Hindî şairlerinde de olmakla birlikte Türk şiirinde yabancılaştırıcı etksi daha fazladır. Bazen metnin anlaşılmasını güçleştirecek Farsça tamlama şekillerinin ortaya çıktı̆̆ da bir gerçektir. Özellikle ters çevrilmiş (izâfet-i maklûb) ve kısaltılmış tamlamalar (izâfet-i maktû') ile birlikte bu tarz tamlamaların anlaşılması ve günümüz Türkçesine doğru bir şekilde aktarılması güçleşmiştir.

Nâilînnin aşağıdaki beytindeki “çâşnî-senc-i hayât-âverî-yi güftâr” terkibini inceleyelim:

Nâz eder Hızr u Mesîhâya lebün oldukça

Çâşnî-senc-i hayât-âverî-yi güftârun (Nâilî G.203/3)

Bu tür tamlamalarda tamlanan unsur (çâşnî-senc) bazen bir yardımcı fiile bağlanabilir. Dolayısıyla beyit içindeki öğelerin birbiriyle irtibatını doğru bir şekilde tesbit etmeden terkibi tek başına Türkçe tamlamaya çevirip mısraın içine yerleştirmek bazen yanıltıcı olabilir. Bu sebeple önce terkipte hiçbir değişiklik yapmadan beyti nesre çevirelim:

Lebün, çâşnî-senc-i hayât-âverî-yi güftârun oldukça Hızr u Mesîhâya nâz eder.

Buna göre terkibin tamlananı konumundaki çâşn̂-senc ile -olmak fiili birlikte ele alınmalıdır. Terkibin tamamı beyti oluşturan cümlenin zarfı durumundadır. Beyit günümüz Türkçesine şöyle aktarılabilir:

Dudağın, sözünün hayat verici tadını ölçtükçe (değerini anladıkça) Hızır ve Mesîhâya naz eder.

Dudak, Hızır ve Hz. Îsâ arasındaki münasebet malumdur. Zincirleme tamlamaların tercih edilmesi Hint üslubu şairlerinin az sözle çok şey anlatma (îcâz) arzularının bir sonucu olabilir. Sâmînnin şu beytiyle bu hususiyeti açıklamaya çalışalım:

Biz esîr-i 'işretüz sâkîlerün meftûnıyuz

Beste-i zencîr-i mevc-i bâde-i gül-gûnıyuz (Sâmî G.53/1)

(Biz işret esiriyiz ve sakilere tutkunuz. [Onun] gül renkli badesinin dalgasının zincirine bağlıyız.)

İkinci mısrada bâde etrafında halka halka demetlenen benzetmelere ve hayal örgüsüne baktığımızda şunları görürüz:

1. Gül renkli (kırmızı) bir şarap (Gülün yapraklarının kat kat olması ile dalga arasındaki benzerlik). 2. Şarapın üzerinde dalgalardan söz edilmektedir (Deniz çağrışımı). 3. Şarapın üstündeki dalgalar (halkalar) zincire benzetiliyor. 4. Şair gül renki şarabın üstündeki zincire benzeyen dalgalara bağlıdır. 5 . Bütün bu kavramlar ilk mısradaki esîr, meftûn, işret, sâkî kavramlarıyla da ilişkilidir.

Diğer örnekleri günümüz Türkçeleriyle vermek yeterli olacaktır:

Dil teh-nişîn-i halka-i gird-âb-ı zülf-i yâr

Baht-i siyâh hande ider karadan bana (Sâmî G.5/4)

(Gönül, sevgilinin saçının girdap halkasının dibinde oturur. Kara bahtım ise karadan [sahilden] bana güler.) 
Cürmüm ikrâr etdiren bismilgeh-i âşûbda

Haşyet-i cellâd-ı çeşm-i pür-tegâfüldürr bana (Nâilî-i Kadîm G.6/5)

(Kargaşa mezbahasında bana suçumu itiraf ettiren şey, ziyadesiyle bilmezlenen göz celladından duyduğum korkudur.)

Benem o şîr-i kavî-dest-i bîşe-zâr-ı cünûn

Egerçi derd-i cünûna olur devâ zencîr (Fehîm-i Kadîm G.65/4)

(Her ne kadar delilik derdine zincir çare olsa da ben delilik ormanının o eli kuvvetli arslanıyım.)

Olaldan reh-neverd-i nakş-ı pây-ı edhem-i nâzük

Tenük-çeşmân-ı aşka tûtiyâdır gerd-i istiğnâ (Şeyh Gâlib G.10/4)

(Nazik kara yağız atın ayak izinin takipçisi olduğundan beri, aşkın zayıf gözlerine istiğna tozu sürme olmuştur.)

\section{Sonuç}

Hint üslubu şairlerinin şiirin nasıl olması gerektiğine dair öne sürdükleri birtakım kavramlar (ma’nâ-yı bîgâne, ma’nâ-yı pîçîde, ma'nâ-yı dûr, hayâl-i nâzik gibi) ve şiirlerinde ortaya çıkan yeniliklerin tedkik edilmesi sayesinde bu yeni tarzın hususiyetleri tespit edilebilmektedir. Şiirdeki ifade biçiminin alışılmadık bir tarzda olması, kolay anlaşılabilir olmaması, yeni hayallerle beslenmesi gerektiği gibi düşünceler yabancılaştırma tekniği denilen sanat anlayışıyla benzerlikler gösterir. Dolayısıyla yabancılaştırma kuramında edebiyat metni için teklif edilen yöntemin, Hint üslubunda bir ölçüde hususiyet olarak müşahade edildiğini söyleyebiliriz.

Pratik ile yöntem arasındaki bu örtüşmenin yanında bir farklllı̆̆a dikkat çekmek gerekir. Yabancılaştırma kuramı önerdiği sanat anlayışını birtakım gerekçelere dayandırır. Hint üslubunda ise bu kadar sarih ve billurlaşmış bir gerekçe söz konusu değildir. Onun yerine Hint üslubunu hazırlayan sosyal ve siyasi şartlardan bahsetmek mümkündür. Bunların başında Safevî yönetiminin baskıları şiirin kapalı bir hâle bürünmesinde bir âmil olarak zikredilmektedir. Ayrıca baskıdan kaçan şairlerin Hint sarayı etrafında toplanmaları ve bu süreçte Hint düşüncesinden etkilenmeleri de bir diğer sebep olarak dile getirilir. Bununla beraber Hint - İran sahası dışında kalan Osmanlı - Türk coğrafyasında bu şiir anlayışının kabul görmesi, söz konusu şiir anlayışının tercih edilmesinde estetik kaygıların da rol oynadığının bir işareti olarak kabul edilebilir. Nitekim bazı şairlerin bîgâne ve pîçîde bir mazmun bulmaktan ve bunun idrakinden aldıkları lezzeti dile getirdiklerini görmüştük. Bu anlayış Shklovsky'nin de algı sürecini estetik bir netice olarak görmesi ve uzaması gerektiği düşüncesiyle uyumludur.

Hint üslubunda yabancılaştırıcı unsurlar olarak zikrettiğimiz hususiyetlerden birçoğu dilde hazır bulunan formların "alışılmamış" nesnelere ve kavramlara izafe edilmesinden oluşmaktadır. Örneğin his karmaşası (hiss-âmizî), paradoksal ifadeler veya somutlaştırmalar gündelik dilde ve/veya klasik üslup şairlerinde de rastlanan hususlardır. Fakat bu formların dilsel olarak tecrübe edilmemiş bir yönde kullanılması, yani alışılmamış bağdaştırmalar oluşturulması metnin algılanmasını yavaşlatan "yabancılaştırıcı" bir etki yaratmıştır.

Yeni mazmunlar bulma peşindeki şairin geleneğe, gündelik hayata, çevreye ve dile yönelen dikkati bazen eski bir mazmuna yeni bir yorum getirmiş, bazen de şiire yeni bir mazmun armağan etmiştir. Bu mazmunlar içerisinde yer yer zihnin daha güç intikal edebileceği, aşırı hayale dayanan örnekler ortaya çıkmıştır. Elbette aşırı hayalcilik ve giriftlik konusunda ifrâtiyyûn ve îtidâliyyûn koluna mensup şairler arasında bir fark olduğunu da unutmamak gerekir. Netice itibariyle az veya çok bu tür mazmunlar da şiirde yabancılaştırıcı bir etki oluşturmuştur. 
Hint üslubunda ortaya çıkan bu ifade biçimlerinin klasik şiir geleneği içinden neşet etmiş fakat ondan belli ölçüde farklılaşmış poetik bir düşünme biçimi olduğu söylenebilir. Bu şiir üslubunun içerdiği yabancı ve alışılmamış manalar, okur tarafından keşfedilmeyi bekleyen istiareler, teşbihler, mana münasebetlerinden oluşmaktadır.

Şiirin zihnileşmesi, manasına güçlükle nüfuz edilebilen mazmun ve nükteler, alışılmamış bağdaştırmalar kimilerince ilgiyle karşılanmış ve benimsenmiş, bazı kimseler tarafından ise - bilhassa yakın zamana kadar İran'da - divan şiirinin bahçesinde dolaşan bir “yabancı” gibi algılanmış ve yadırganmıştır.

\section{Kaynakça}

Akdoğan, Y. (tarih yok). Ahmedî Divanı. Ankara: Kültür ve Turizm Bakanlı̆̆ı Yayınları. http://ekitap.kulturturizm.gov.tr adresinden alındı

Akkaya, H. (1994). Nevres-i Kadim ve Türkçe Divanı (Yayımlanmamış Doktora Tezi). İstanbul: Marmara Üniversitesi SBE.

Akkuş, M. (1993). Nefî̀ Divanı. Ankara: Akçağ Yayınları.

Âlâştî, H. H. (1384/2004). Ma'nâ-yı Bîgâne Der Şi'r-i Sâib-i Tebrîzî. Neşriye-i Dânişkede-i Edebiyât (Tebrîz), 48(196), 69-84.

Arı, A. (2011). Sâkıb Dede ve Dîvânı. Ankara: Kültür ve Turizm Bakanlığı. http://ekitap.kulturturizm.gov.tr adresinden alındı

Arslan, M., \& Aksoyak, İ. H. (tarih yok). Haşmet Külliyatı. Ankara: Kültür ve Turizm Bakanlığı Yayınları. http://ekitap.kulturturizm.gov.tr adresinden alındı

Babacan, İ. (2010). Klasik Türk Şiirinin Son Baharı Sebk-i Hindî. Ankara: Akçă̆ Yayınları.

Behdarvend, E. (1392/2013). Dîvân-ı Bîdil-i Dihlevî. Tahran: İntişârât-ı Nigâh.

Bektaş, E. (2007). Muvakkit-zâde Muhammed Pertev Dîvânı. Ankara: Kültür ve Turizm Bakanlığı Yayınları. http://ekitap.kulturturizm.gov.tr adresinden alındı

Beyzâî, P. (1336). Dîvân-ı Ebû Tâlib Kelîm-i Kâşânî. Tahran: Kitâb-fürûşî-yi Hayyâm.

Bilkan, A. F. (1997). Nâbî Dîvânı. İstanbul: M.E.B.

Cuddon, J. A. (2013). A Dictionary of Literary Terms and Literary Theory. Oxford: Wiley-Blackwell Publishing.

Demirel, Ş. (2017). Şehrî Dîvânı. Ankara: Kültür ve Turizm Bakanlığı. http://ekitap.kulturturizm.gov.tr adresinden alındı

Efsah-zâd, A. (1378). Dîvân-ı Câmî I (Fâtihatüş-Şebâb). Tahran: Merkez-i Mutâlaât-ı Îrânî.

Ensârî, M. V. (1378). Külliyât-ı Örfî-yi Şîrâzî. Tahran: İntişârât-ı Dânişgâh-ı Tahrân.

Gencevî, N. (tarih yok). Heft Peyker. Haziran 16, 2019 tarihinde Ganjoor: https://ganjoor.net/nezami/5ganj/7peykar/ adresinden alındı

Güfta, H. (2001). Erzurumlu Şair Hâzık. İstanbul: Erzurum Kitaplığı.

Gürer, A. (2000). Şeyh Gâlib’in Şiirlerinde Bir Anlatım Özelliği. Türkoloji Dergisi, XIII(1), 99-108.

Habib, M. A. (2005). A History of Literary Criticism: From Plato to the Present. Malden: Blackwell Publishing.

Hak-cû, S. (1390). Sebk-i Hindî ve İstiâre-i Îhâmî-yi Kinâye. Bahâr-1 Edeb, IV(1), 255-268.

Hakcû, S., \& Rızâyî, M. M. (1397). Berresî Yekî ez Râhhâ-yı Bîgâne-sâzî der Sebk-i Hindî: Mutâlaa-i Movredî Gazelhâ-yı Sâib. Fünûn-ı Edebî, X(1), 70-85. 
İlhâmî, Ş. (1387). Berresî-yi Hissâmizî der Gazeliyyât-ı Bîdil-i Dihlevî. Fasılnâme-i Edebiyât-ı İrfânî ve Ustûre-şinâhtî, 4(12), 32-48.

İpekten, H. (1970). Nâilî-i Kadîm Dîvânı. Ankara: MEB Yayınları.

Kaçar, M. (2018). Şeyh Gâlib'in "Tûtî-i Zenbûr"u Bir Çiçek Olabilir Mi? Artuklu İnsan ve Toplum Bilim Dergisi, III(2), 54-59.

Kahraman, M. (1364/1985). Dîvân-ı Sâib-i Tebrîzî. Tahran: Şirket-i İntişârât-ı İlmî ve Ferhengî.

Kaplan, M. (1996). Neşâtî Divanı. İzmir: Akademi Kitabevi.

Kasır, H. A. (1990). Esrar Dede / Hayatı, Edebi Kişliği ve Divanının Karşılaştırmalı Metni (Yayımlanmamış Doktora Tezi). Erzurum: Atatürk Üniversitesi SBE.

Kutlar, F. S. (2004). Arpaemîni-zâde Sâmî Divanı. Ankara: Kültür ve Turizm Bakanlı̆̆ı. Ekim 10, 2017 tarihinde http://ekitap.kulturturizm.gov.tr adresinden alındı

Kutlar, F. S. (2009). Arpaemînizâde Sâmî’nin ‘Ta'kid’ Örneği Beyti Üzerine. Turkish Studies, IV(6), 346359.

Macit, M. (2017). Nedîm Dîvânı. Ankara: Kültür ve Turizm Bakanlı̆̆ı. http://ekitap.kulturturizm.gov.tr adresinden alındı

Mansûr, C. (1378). Dîvân-ı Rubâiyât-ı Ebû Saîd Ebû’l-Hayr. Tahran: İntişârât-ı Nâhîd.

Mermer, A. (1991). Mezâkî Hayatı, Edebi Kişiliği ve Divanı'nın Tenkitli Metni. Ankara: Atatürk Kültür Merkezi Yayınları.

Mum, C. (2005). Sebk-i Hindî'de Beyit Yapısı, Paradoksal İmajlar ve Çoklu Duyulama. H. Aynur, M. Çakır, \& H. Koncu (Dü) içinde, Sözde ve Anlamda Farklılaşma Sebk-i Hindî (s. 108-141). İstanbul: Turkuaz.

Okçu, N. (tarih yok). Şeyh Gâlib Dîvânı. Ankara: Kültür ve Turizm Bakanlığı. http://ekitap.kulturturizm.gov.tr adresinden alındı

Özdemir, M. (1999). Neccâr-zâde Rızâ Divânı' nın Edisyon Kritiği (Yüksek Lisans Tezi). Afyon: Kocatepe Üniversitesi SBE.

Saraç, Y. (2002). Klâsik Edebiyat Bilgisi Belâgat. İstanbul: Bilimevi.

Sekkâkî. (2017). Miftâhu'l-Ulûm Belâgat. (Z. Çelik, Çev.) İstanbul: Litera Yayıncılık.

Siyâkî, M. D. (1347). Dîvân-ı Menûçehrî Damgânî. Tahran: Kitâb-fürûşî-yi Zevvâr.

Şafak, T. (1386). Tashîh-i İntikâdî-yi Dîvân-ı Şevket-i Buhârî (Yayımlanmamış Doktora Tezi). Tahran: Dânişgâh-ı Tahrân.

Şahâb, T. (1361). Külliyât-ı Eş'âr-ı Melikü'ş-şuarâ Tâlib-i Âmulî. Tahran: Kitâbhâne-i Senâî.

Şentürk, A. A. (2016). Osmanlı Şiiri Kılavuzu (Cilt I). İstanbul: OSEDAM.

Tarlan, A. N. (1990). Ali Nihad Tarlan'ın Makalelerinden Seçmeler. Ankara: Atatürk Kültür Merkezi Yayını.

Üskûyî, N. (1383). Revişhâ-yı Âşinâyî-zodâyî der Şi'r-i Sâib-i Tebrîzî. Pejûhiş-nâme-i Ferheng u Edeb, $\mathrm{I}(1), 175-193$.

Üzgör, T. (1991). Fehîm-i Kadîm / Hayatı, Sanatı, Dîvân'ı ve Metnin Bugünkü Türkçesi. Ankara: AKM Yayını. 